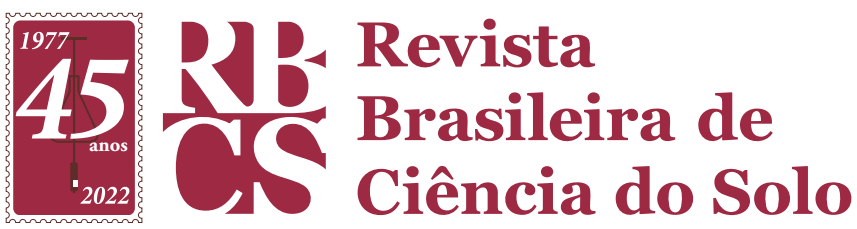

Division - Soil in Space and Time | Commission - Soil Genesis and Morphology

\title{
Soils with dark subsurface horizons in saline basins in the Brazilian Pantanal
}

\author{
Andressa Rosas de Menezes ${ }^{(1) *}\left(\mathbb{D}\right.$, Ademir Fontana ${ }^{(2)} \mathbb{D}$, Lúcia Helena Cunha dos \\ Anjos $^{(1)}$ (D), Marcos Gervasio Pereira ${ }^{(1)}$ (D) and Jolimar Antônio Schiavo ${ }^{(3)}$ (iD) \\ (1) Universidade Federal Rural do Rio de Janeiro, Departamento de Solos, Seropédica, Rio de Janeiro, Brasil. \\ ${ }^{(2)}$ Empresa Brasileira de Pesquisa Agropecuária, Embrapa Solos, Campo Grande, Mato Grosso do Sul, Brasil. \\ (3) Universidade do Estado do Mato Grosso do Sul, Departamento de Solos, Aquidauana, Mato Grosso do Sul, \\ Brasil.
}

\begin{abstract}
Soils in the Brazilian Pantanal classified as Espodossolos and registered in the literature diverge from the central concept of pedogenesis by podzolization, especially due to the high values of $\mathrm{pH}$ and basic cations, although the morphology is similar to that of spodic horizons. In this sense, this study hypothesized that the neutral to alkaline conditions along the edges of the saline basins in the Lower Nhecolândia region do not inhibit the podzolization process nor the development of spodic soils. The objectives were to analyze the attributes of soils with spodic features and evaluate whether they correspond to a podzolization process. Four profiles in a transect in Lower Nhecolândia were selected, where the morphology indicated the presence of a spodic horizon. Three profiles (P1, P2 and P4) were located in a bay and one in the transition between a bay and a "cordilheira" (small elevation between lagoons) (P3). The soils were analyzed for particle size, chemistry and X-ray fluorescence (XRF), as well as organic carbon (C org), total carbon (TC) and XRF of the nodules. The complexity of features and characteristics of soil profiles in the Lower Nhecolândia region indicate multiple pedogenetic processes in this environment. The characteristics of all profiles denote a redoximorphic process: poor profile development (except for P3), mottles formed by precipitation of Fe and $\mathrm{Mn}$ oxides, as well as presence of $\mathrm{Fe}$ and $\mathrm{Mn}$ nodules. The organic matter content of these nodules is mostly greater than or equal to that of the surrounding material, and aluminum is relatively not higher than in the fine earth. This reinforces a rexodimorphic process in the horizons with spodic features. The occurrence of sodic and solodic characters, as well as clay accumulation in P3 also characterize the sodification process. The neutral to alkaline $\mathrm{pH}$ values in water, high sum of bases and low $\mathrm{C}$ org and $\mathrm{Al}$ oxide contents of the studied soils all contradict the occurrence of a podzolization process. However, $\mathrm{Fe}, \mathrm{Al}$ and $\mathrm{C}$ org accumulation in the nodules and some $\mathrm{B}$ horizons indicate a spodic character. Also, the fact that SiBCS criteria classify the studied soils as Espodossolos indicates the relevance of establishing limits for chemical attributes, which would adjust the taxonomy of soils with a spodic character according to their pedogenesis.
\end{abstract}

Keywords: sedimentary pedoenvironment, pedogenesis, podzolization, spodic horizon.
Copyright: This is an open-acces article distributed under the terms of the Creative Commons Attribution License, which permits unrestricted use, distribution, and reproduction in any medium, provided that the original author and source are credited. 


\section{INTRODUCTION}

Spodic horizons are the result of a process of podzolization. They occur mainly in pedoenvironments in humid climate, both temperate and tropical, the parent material consists of felsic rocks or highly permeable sediments and the texture is sandy, mostly with low levels of basic cations causing organic matter dispersion or forming cation-organic matter complexes in the subsurface horizons (De Coninck, 1980; Sauer et al., 2007; Kämpf and Curi, 2012; IUSS Working Group WRB, 2015; Santos et al., 2018). According to the World Reference Base for Soil Resources (WRB; IUSS Working Group WRB, 2015), the subsurface horizon which "contains illuvial substances composed of organic matter and $\mathrm{Al}$ or of illuvial Fe" is defined as a spodic diagnostic horizon. In the Brazilian Soil Classification System (SiBCS; Santos et al., 2018), spodic horizons are dominated by illuviated active amorphous material composed of organic matter and aluminum (Al), with or without iron (Fe).

As in the temperate climate regions (Guillet et al., 1975; Beyer, 1996; Ferro-Vázquez et al., 2014; Valerio et al., 2016; Brock et al., 2020), soils with spodic horizons in Brazil mainly have a sandy texture, with subsurface accumulation of organic carbon, acidic-range $\mathrm{pH}\left(\mathrm{H}_{2} \mathrm{O}\right)$ and low base saturation. However, in Brazilian soils with spodic horizons, the levels of $\mathrm{Fe}$ and $\mathrm{Al}$ oxides and organic carbon ( $\mathrm{C}$ org) are much lower than in temperate environments; in most freely drained environments, the profiles have a surface horizon with low C org content and a thick eluvial horizon (Menezes et al., 2018). Poorly drained soils with a spodic horizon may have an $\mathrm{H}$ histic horizon, no or a thin $\mathrm{E}$ horizon, a smooth topography in the transition between horizons and presence of mottles (Buurman et al., 2013; Lopes-Mazzetto et al., 2018).

The Brazilian Soil Classification System (SiBCS) characterizes soils formed by the podzolization process by the presence of a spodic horizon as diagnostic subsurface horizon, classified in the order of Espodossolos (Santos et al., 2018). Such soils occur in all regions of Brazil in different ecosystems: in the Amazon basin (Ishida et al, 2018; Tadini et al., 2018), coastal tablelands (Rêgo et al., 2019; Schiavo et al., 2020), coastal sandbanks (Buurman et al., 2013; Lopes-Mazzetto et al., 2018; Silva Neto et al., 2018), the Pantanal basin (Schiavo et al., 2012; RCC, 2012), as well as in cold and humid climates of the high-altitude mountains in the Atlantic Forest biome (Schaefer et al., 2002; Simas et al., 2005).

In a previous study, Menezes et al. (2018) reported wide variation in the morphological and chemical attributes of spodic horizons of 154 Brazilian profiles described as Espodossolos in the literature. Among these profiles, those in the Pantanal had a particularly high $\mathrm{pH}\left(\mathrm{H}_{2} \mathrm{O}\right)$ and high sodium $(\mathrm{Na})$ and low $\mathrm{C}$ org and $\mathrm{Al}$ contents. These conditions diverge totally from the central concept of the podzolization process and the current definition of spodic horizons in the international soil classification systems and literature (De Coninck, 1980; Chesworth and Macias-Vasquez, 1985; Lundström et al., 2000; Sauer et al., 2007; IUSS Working Group WRB, 2015).

The Pantanal has a unique hydrology and geomorphology and is a special biome as well, but pedology studies in this environment are still scarce. This reinforces the relevance of describing, characterizing and understanding soils with "spodic features", including their pedogenetic processes, reported in the literature for large areas of the Pantanal. In addition, studies about these soils may provide information to better define the Espodossolos soil order in the SiBCS (Santos et al., 2018).

Considering the uniqueness of the soils with spodic features reported in the Pantanal, compared to other environments of Brazil (Menezes et al., 2018), this study hypothesized that the neutral to alkaline conditions, found along the edges of saline basins in the Pantanal wetlands, do not inhibit the podzolization process and the development of spodic soils. In this sense, the objectives were to analyze the attributes of soils with 
spodic features in the Lower Nhecolândia region and to evaluate if they correspond to the podzolization process.

\section{MATERIALS AND METHODS}

\section{Brazilian Pantanal in the Lower Nhecolândia subregion}

The Pantanal wetland of Brazil is characterized by predominantly flat lowlands and strongly influenced by the water regime of the Upper Paraguay river Basin (IBGE, 2019a). This region in the Midwest of Brazil is the largest inland flooded area in the world (approximately 150,988 km²) (IBGE, 2019a). The Paraguay river is the main collector of waters from several affluents, the largest of which is the fluvial megafan of the Taquari river. The Pantanal wetland of Brazil covers an approximate area of $49,000 \mathrm{~km}^{2}$, with elevations of $85-190 \mathrm{~m}$, i.e., the average topographic gradient is very low $\left(0.36 \mathrm{~m} \mathrm{~km}^{-1}\right)$ (Assine, 2005; Zani et al., 2012).

This study was carried out specifically in the Lower Nhecolândia, a Pantanal subregion in the southwest of the Taquari megafan. This region is characterized by thousands of rounded lagoons, which can contain fresh water, as in bays, or brackish water in salines. These waterbodies are set among specific formations, regionally known as "cordilheiras", "vazantes" or "corixos", according to their peculiar features (Boin et al., 2019). The "vazantes" are several kilometers long, temporary channels that connect the bays during the flood season, similar to the "corixos", which can however remain dry for years. The "cordilheiras", different from what the name would suggest, are small elevations of about $2 \mathrm{~m}$ above the level of the lagoon around them.

The Lower Nhecolândia subregion is covered by sandy clay sediments from the Pantanal Formation, with incipient clay and organic matter stratification and cemented by ferruginous material, but without current sediment input (Godoi et al., 2001; Assine, 2005). The soils are substantially sandy, with predominance of fine sand and salt accumulation, and may have a textural gradient (Furquim et al., 2010, 2017; RCC, 2012; Schiavo et al., 2012; Boin et al., 2019; IBGE, 2019b; Andrade et al., 2020). Specifically, soils with spodic features occur in periodically flooded areas, such as bays, salines and "cordilheiras" (RCC, 2012; Schiavo et al., 2012), normally under deciduous tropical Cerradão (woodland savanna) and tropical Cerrado (open shrub) vegetation.

Local climate is Aw (tropical with summer rains), according to the Köppen-Geiger climate classification (Aparecido et al., 2020). Due to the predominantly flat relief, the soil moisture rises rapidly even after small rainfall events and consequently the water table. About 30 to 60 days after the beginning of the rainy season in October, the percentage of flooded areas started to increase and peaked (70 - $75 \%$ ) in May (Hamilton et al., 1998). According to the climatological normal of the Nhumirim Agroclimatic Station, located in the study area, the cumulative annual rainfall is $1,176.4 \mathrm{~mm}$ and the dry period normally begins in April; the annual means are $25.4^{\circ} \mathrm{C}, 82 \%$ relative air humidity and $1,521.2 \mathrm{~mm}$ evaporation (Soriano, 2000).

\section{Site prospection, soil profile sampling and description}

The study area belongs to the Fazenda Nhumirim of Embrapa Pantanal, located in the Lower Nhecolândia, Corumbá, Mato Grosso do Sul, Brazil. Soil surveys with mapping units that described Espodossolos (Fernandes et al., 2007; Santos et al., 2011) and other studies on soil profiles of this order (RCC, 2012; Schiavo et al., 2012) were analyzed. Representative sites of soils with spodic features were identified in the field with an auger (Figure 1).

Selected study profiles consisted of a small group near or at the edge of a saline basin, as a result of a detailed search in a larger area for the best pedoenvironment 

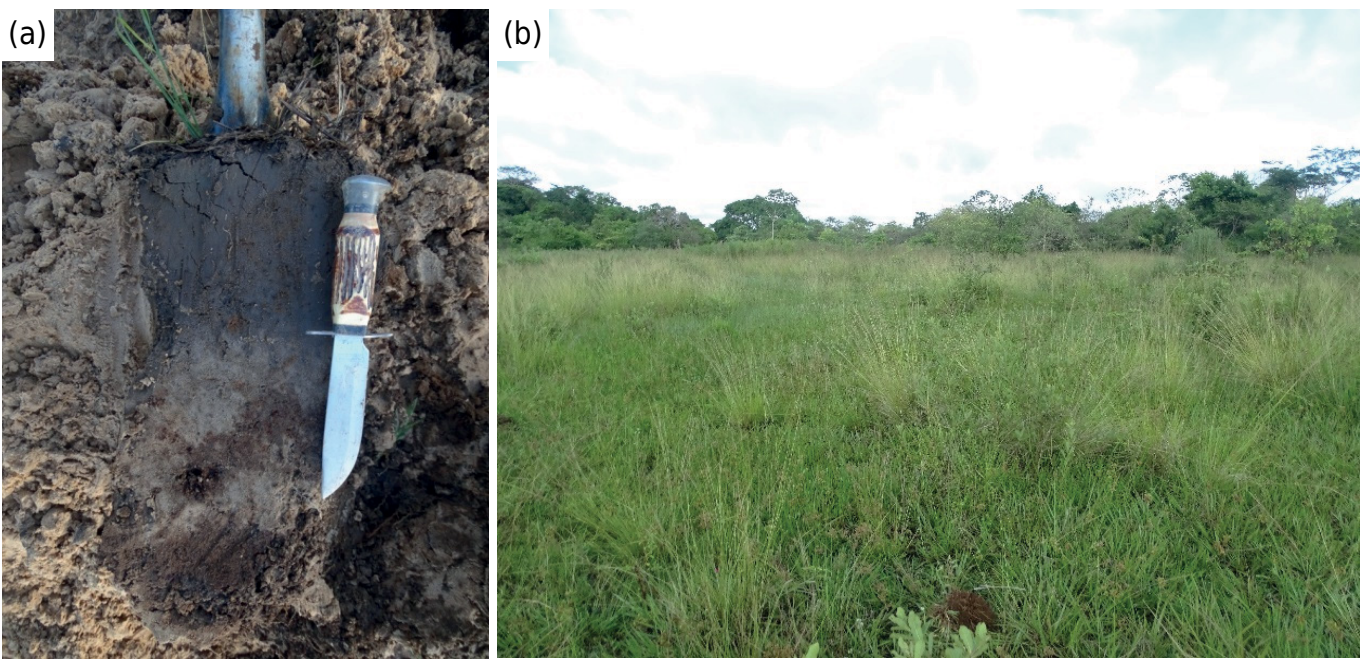

Figure 1. Auger with a sample of the surface layer $(0.00-0.20 \mathrm{~m})(\mathrm{a})$ and landscape of the profiles with spodic features in the Pantanal of Lower Nhecolândia, Mato Grosso do Sul (b).

for the occurrence of spodic horizons. Based on that survey, a small area of greater representativity and concentration of spodic morphological features was defined for the description and sampling of soil profiles. Thus, previous descriptions in the literature of the landscape conditions in which these soils occur were considered, and the selected site can be defined as a small, highly representative area of the study subject in Lower Nhecolândia. It was not possible to open a trench all along the transect to evaluate the lateral continuity of the features. Although the large lateral variation in properties of Espodossolos is often described in the literature, it was not an objective of this study to evaluate them.

In November 2018, four trenches in parts of a transect were opened. Soil samples were taken and the profiles morphologically described as proposed by Santos et al. (2015) (Figure 2). The profile selection was based on features that could indicate a spodic horizon, according to the morphological criteria defined by SiBCS (Santos et al., 2018) and WRB (IUSS Working Group WRB, 2015).

\section{Sample preparation, laboratory analysis and soil classification}

After manual fragmentation, the crumbled soil samples were dried in a forced air circulation oven at $40{ }^{\circ} \mathrm{C}$ and sieved $(<2 \mathrm{~mm})$ to obtain air-dried fine earth. The samples were prepared and analyzed according to Teixeira et al. (2017). Particle-size analysis was performed using the pipette method. The total sand fraction was divided into very coarse (2.00-1.00 mm), coarse (1.00-0.50 mm), medium $(0.50-0.210 \mathrm{~mm})$, fine $(0.210-0.10 \mathrm{~mm})$ and very fine sand $(0.10-0.05 \mathrm{~mm})$.

Sequentially, the $\mathrm{pH}\left(\mathrm{H}_{2} \mathrm{O}\right.$ and $\left.\mathrm{KCl}\right)$, cationic complex, organic carbon, soluble salts and electrical conductivity were determined from the fine earth fraction. The $\mathrm{Ca}^{2+}, \mathrm{Mg}^{2+}$ and $\mathrm{Al}^{3+}$ were extracted with $1 \mathrm{~mol} \mathrm{~L}^{-1} \mathrm{KCl}$, while $\mathrm{H}+\mathrm{Al}$ was extracted with $0.5 \mathrm{~mol} \mathrm{~L}^{-1}$ $\mathrm{Ca}\left(\mathrm{C}_{2} \mathrm{H}_{3} \mathrm{O}_{2}\right)_{2}$ at $\mathrm{pH}$ 7.0. For $\mathrm{Na}^{+}$and $\mathrm{K}^{+}$, extraction was carried out with $0.0125 \mathrm{~mol} \mathrm{~L}^{-1}$ $\mathrm{H}_{2} \mathrm{SO}_{4}+0.05 \mathrm{~mol} \mathrm{~L}^{-1} \mathrm{HCl}$. The levels of $\mathrm{Ca}^{2+}$ and $\mathrm{Mg}^{2+}$ were determined by titration with $0.0125 \mathrm{~mol} \mathrm{~L}^{-1}$ EDTA, $\mathrm{Na}^{+}$and $\mathrm{K}^{+}$by flame photometry and $\mathrm{Al}^{3+}$ and $\mathrm{H}+\mathrm{Al}$ by titration with $0.025 \mathrm{~mol} \mathrm{~L}^{-1} \mathrm{NaOH}$. The $\mathrm{pH}$ in water and $\mathrm{KCl}(1: 2.5)$ were determined with a potentiometer. Organic carbon was quantified by oxidation with $0.0667 \mathrm{~mol} \mathrm{~L}^{-1} \mathrm{~K}_{2} \mathrm{Cr}_{2} \mathrm{O}_{7}$ and titration with $0.1 \mathrm{~mol} \mathrm{~L}^{-1} \mathrm{Fe}\left(\mathrm{NH}_{4}\right)_{2}\left(\mathrm{SO}_{4}\right)_{2} \cdot 6 \mathrm{H}_{2} \mathrm{O}$. The nodules were ground to determine organic carbon by wet oxidation and total carbon using a Perkin-Elmer $2400 \mathrm{CHNS} / 0$ elemental analyzer. The reference standard for total carbon analysis was acetanilide ( $C=71.09 \%, \mathrm{H}=6.71 \%, \mathrm{~N}=10.36 \%$ ). 

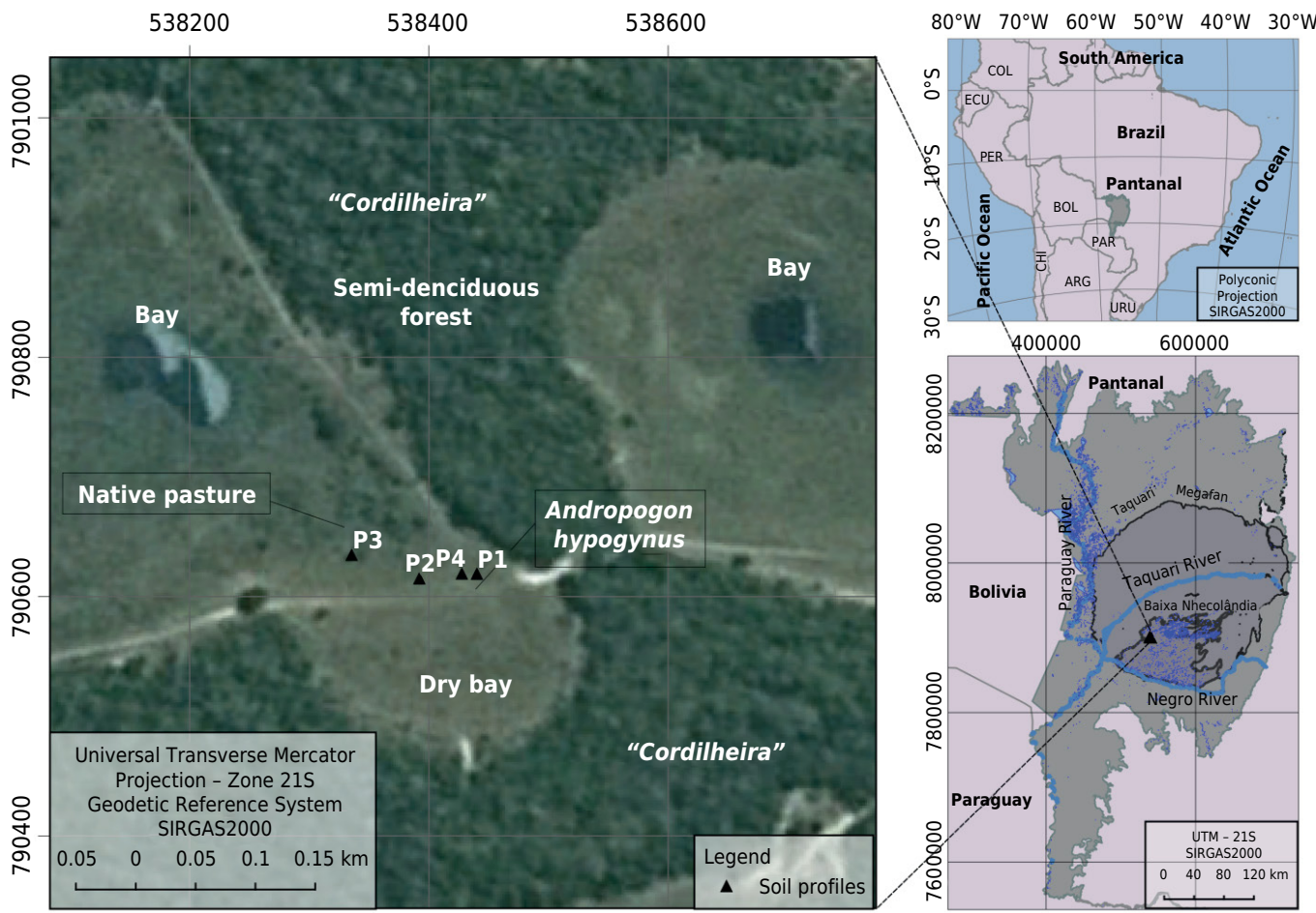

Figure 2. Soil profiles in the Pantanal of Lower Nhecolândia, Mato Grosso do Sul. Sources: Shapefile of Brazilian biomes - IBGE (2019a); cartographic base - IBGE (2019c); image of study area - Google Earth Pro.

Soluble salts $\left(\mathrm{Na}^{+}\right.$and $\left.\mathrm{K}^{+}\right)$were extracted from the fine earth fraction in aqueous medium and analyzed by flame photometry. Afterwards, the electrical conductivity of the saturation extract was measured by a digital conductivity meter. To identify carbonates and $\mathrm{Mn}$ oxides, respectively, the effervescence of the samples was evaluated with $10 \% \mathrm{HCl}$ and hydrogen peroxide (20 volumes) (Santos et al., 2015).

Sulfuric acid (solution ratio of $1: 1$ ) was used for extraction from the fine earth fraction to determine $\mathrm{Fe}_{2} \mathrm{O}_{3}$ and $\mathrm{Al}_{2} \mathrm{O}_{3}$ contents. The pedogenetic oxides $\mathrm{Fe}, \mathrm{Al}$ and $\mathrm{Mn}$ were also measured in the fine earth fraction, after extraction with sodium dithionite-citrate-bicarbonate solution $\left(\mathrm{Fe}_{d}\right.$ and $\left.\mathrm{Mn}_{\mathrm{d}}\right)$ and ammonium oxalate acid $\left(\mathrm{Fe}_{0}, \mathrm{Al}_{0}\right.$ and $\left.\mathrm{Mn}_{0}\right)$. The ratio $\mathrm{Fe}_{0} / \mathrm{Fe}_{\mathrm{d}}$ was calculated to evaluate the predominance of more or less crystalline forms of $\mathrm{Fe}$ oxides in the horizons.

For the elemental composition of $\mathrm{Si}, \mathrm{Fe}, \mathrm{Al}, \mathrm{Ti}, \mathrm{Mn}$ and $\mathrm{P}$ by $\mathrm{X}$-ray fluorescence (XRF), fine earth fraction and nodule samples were prepared according to the glass bead method. The samples were ground in a vibrating mill and then $0.5000 \mathrm{~g}$ was weighed directly into a platinum crucible together with $5.0000 \mathrm{~g}$ of lithium tetraborate/lithium metaborate mixture (66/34\%). After the material was blended, the crucible was taken to an Eagon 2 automatic melting machine for fusion to glass beads at $1050{ }^{\circ} \mathrm{C}$ for $26 \mathrm{~min}$. Most samples were subjected to only one, but some to a second melting cycle, in case of incompletely melted material.

The spectra of the glass beads were obtained by wavelength dispersive $X$-ray fluorescence spectrometry (WD-XRF; ZSX Primus; Rigaku) using a rhodium (Rh) tube. Samples were read once, for an average period of $16 \mathrm{~min}$. Readings were based on a quantitative curve in empirical mode, constructed from reference samples (Table 1).

The reference standards of the multielement curve for sample quantification are specified in table 2. Data import was performed using ZSX software. The oxide forms of each element were obtained after applying the following conversion factors: $\mathrm{Si}_{\text {to }} \mathrm{SiO}_{2}: 2.12$; 
Al to $\mathrm{Al}_{2} \mathrm{O}_{3}: 1.89 ; \mathrm{Fe}$ to $\mathrm{Fe}_{2} \mathrm{O}_{3}: 1.43$; $\mathrm{Ti}$ to $\mathrm{TiO}_{2}: 1.29 ; \mathrm{Mn}$ to $\mathrm{MnO}_{2}: 1.22 ; \mathrm{P}$ to $\mathrm{P}_{2} \mathrm{O}_{5}: 2.29$. Then, the data were converted from percentage to $\mathrm{g} \mathrm{kg}^{-1}$.

For each soil profile, the difference between the $\mathrm{Fe}_{2} \mathrm{O}_{3}$ contents obtained by XRF and by sulfuric acid extraction was calculated. The distribution of $\mathrm{Fe}_{2} \mathrm{O}_{3}$ and $\mathrm{Al}_{2} \mathrm{O}_{3}$ that are not part of the clay fraction was analyzed for a possible relation with organic carbon contents, which is a prerequisite for the podzolization process. Furthermore, in cases where the content of a certain element extracted by the sulfuric acid method exceeded that obtained by XRF, the difference between XRF and sulfuric acid extraction was assigned zero (content) for interpretation and discussion.

Based on the laboratory analyses data and morphological characteristics, the profiles were classified according to the Brazilian Soil Classification System - SiBCS (Santos et al., 2018) and WRB (IUSS Working Group WRB, 2015).

\section{RESULTS}

\section{Pedoenvironment, soil profile morphology and particle-size distribution}

The profiles were selected in two different parts of the transect: three adjacent to a bay area (P1, P2 and P4) and one in the transition between the bay and the "cordilheira" (P3) (Table 3), here named "saline lagoon edge". Profiles P1, P2 and P4 lie in a seasonally flooded area, with a flat relief, covered by "capim vermelho" vegetation (Andropogon hypogynus), at an ellipsoidal elevation of $80 \mathrm{~m}$ (Table 3). Profile P3 lies in a flat relief area, with an ellipsoidal elevation of $82 \mathrm{~m}$ and under a vegetation known locally as "campo limpo" (Table 3). The vegetation is native pasture composed of Mesosetum sp., Setaria geniculata and Rychardia sp., with the occurrence of Bromelia antiacantha, Vernonia polysphaera and Laurus nobilis.

Table 1. Parameters adopted in the quantitative curve for sample readings by XRF

\begin{tabular}{lcccc}
\hline Element & Line & Crystal & Angle (deg) & Detector \\
\hline $\mathrm{Al}$ & $\mathrm{K} \alpha$ & $\mathrm{PET}$ & 144.712 & $\mathrm{PC}$ \\
$\mathrm{Fe}$ & $\mathrm{K} \alpha$ & $\mathrm{LiF} 1$ & 57.502 & $\mathrm{SC}$ \\
$\mathrm{Mn}$ & $\mathrm{K} \alpha$ & $\mathrm{LiF1}$ & 62.956 & $\mathrm{SC}$ \\
$\mathrm{P}$ & $\mathrm{K} \alpha$ & $\mathrm{PET}$ & 89.392 & $\mathrm{PC}$ \\
$\mathrm{Si}$ & $\mathrm{K} \alpha$ & $\mathrm{PET}$ & 109.006 & $\mathrm{PC}$ \\
$\mathrm{Ti}$ & $\mathrm{K} \alpha$ & $\mathrm{LiF} 1$ & 86.134 & $\mathrm{SC}$ \\
\hline
\end{tabular}

SC: scintillation counter; PC: proportional counter.

Table 2. Reference standards of multi-element curve

\begin{tabular}{|c|c|c|c|c|c|c|}
\hline Reference standards & Al & $\mathbf{F e}$ & Mn & $\mathbf{P}$ & $\mathbf{S i}$ & $\mathrm{Ti}$ \\
\hline & \multicolumn{6}{|c|}{$\%$} \\
\hline Montana Soil I - NIST 2710a & 5.95 & 4.320 & 0.2140 & 0.1050 & 31.10 & 0.311 \\
\hline Montana Soil II - NIST 2711a & 6.72 & 2.820 & 0.0675 & 0.0842 & 31.40 & 0.317 \\
\hline San Joaquin Soil - NIST 2709a & 7.37 & 3.360 & 0.0529 & 0.0688 & 30.30 & 0.336 \\
\hline $\begin{array}{l}\text { Flint Clay - SRM 97b (National } \\
\text { Bureau of Standards) }\end{array}$ & 20.76 & 0.831 & 0.0047 & 0.0200 & 19.81 & 1.430 \\
\hline $\begin{array}{l}\text { Plastic Clay - SRM 98b } \\
\text { (National Bureau of Standards) }\end{array}$ & 14.30 & 1.180 & 0.0116 & 0.0300 & 26.65 & 0.809 \\
\hline $\begin{array}{l}\text { Brick Clay - SRM } 679 \text { (National } \\
\text { Bureau of Standards) }\end{array}$ & 11.01 & 9.050 & 0.1730 & 0.0750 & 24.34 & 0.577 \\
\hline
\end{tabular}


All profiles are marked by the presence of a seasonal high-water table level. Profiles P3 and $\mathrm{P} 4$ are located at the highest and lowest points of the transect, respectively, where the water table, at the time of soil sampling, was 0.45 and $0.43 \mathrm{~m}$ deep (Table 3 ); and between 0.52 and $0.55 \mathrm{~m}$ on $\mathrm{P} 1$ and $\mathrm{P} 2$.

Table 3. Pedoenvironment characterization of soil profiles from the Brazilian Pantanal of Lower Nhecolândia, Mato Grosso do Sul State

\begin{tabular}{|c|c|c|c|c|c|c|}
\hline Profile & Relief & Geomorphological situation & Drainage & Vegetation & Elevation & Water table level \\
\hline & & & & & \multicolumn{2}{|c|}{$\longrightarrow \mathrm{m} \longrightarrow$} \\
\hline P1 & Flat & Bay area & $\begin{array}{l}\text { Imperfectly } \\
\text { drained }\end{array}$ & $\begin{array}{c}\text { "Capim vermelho" } \\
\text { vegetation (Andropogon } \\
\text { hypogynus) }\end{array}$ & 0.80 & 0.52 \\
\hline P2 & Flat & Bay area & $\begin{array}{l}\text { Imperfectly } \\
\text { drained }\end{array}$ & $\begin{array}{c}\text { "Capim vermelho" } \\
\text { vegetation (Andropogon } \\
\text { hypogynus) }\end{array}$ & 0.80 & 0.55 \\
\hline P3 & Flat & $\begin{array}{l}\text { Transition between the bay and } \\
\text { the "cordilheira" }\end{array}$ & $\begin{array}{l}\text { Imperfectly } \\
\text { drained }\end{array}$ & $\begin{array}{l}\text { Native pasture. } \\
\text { Vegetation known as } \\
\text { "campo limpo". }\end{array}$ & 0.82 & 0.45 \\
\hline P4 & Flat & Bay area & $\begin{array}{l}\text { Imperfectly } \\
\text { drained }\end{array}$ & $\begin{array}{c}\text { "Capim vermelho" } \\
\text { vegetation (Andropogon } \\
\text { hypogynus) }\end{array}$ & 0.80 & 0.43 \\
\hline
\end{tabular}

(a)

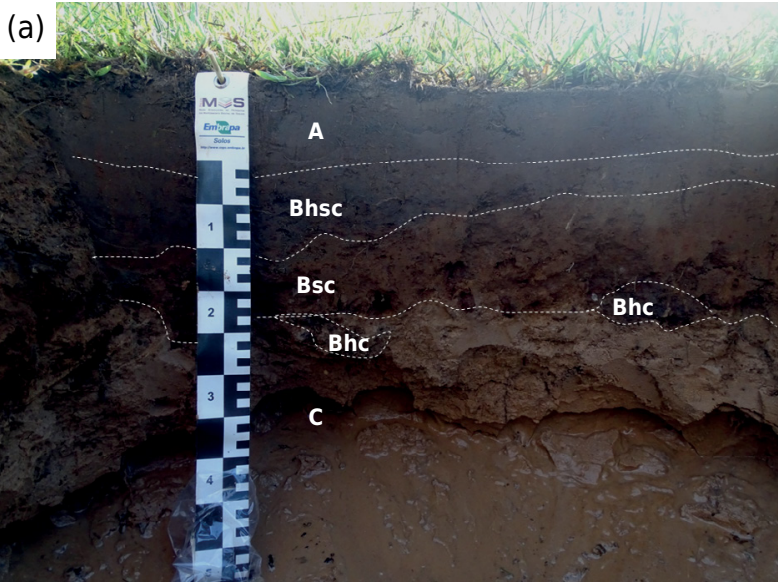

(b)

(c)

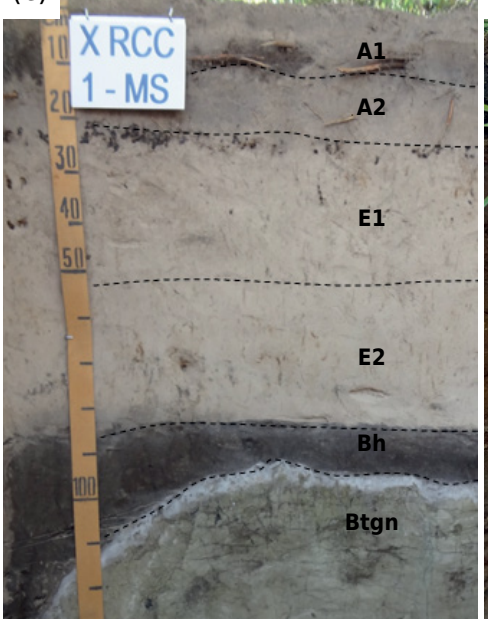

(d)

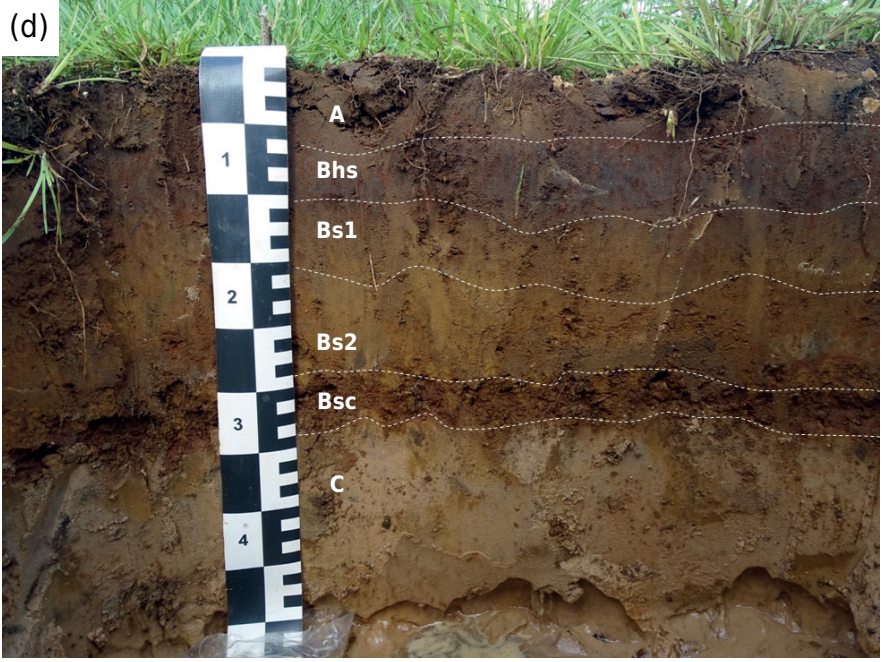

Figure 3. Profiles in a flat relief area, on the edge of a bay (a. P1; b. P2; and d. P4) and in a transition area between a bay and a "cordilheira" (c. MS-1 profile described in the 10th Brazilian Soil Classification and Correlation Meeting, located at the same coordinates as profile P3). On the date of soil collection, horizon B of P3 could not be photographed because of the high water table ( $0.45 \mathrm{~m}$ deep in relation to the surface) in the Brazilian Pantanal. Source of image of P3: Ademir Fontana. 
The profiles in the bay (P1, P2 and P4) have a shallow solum and a horizon sequence of $A, B$ and $C$, except for $P 2$ which has a thin discontinuous $E$ horizon overlaying parts of B (Figure 3). The soil profile in the transitional area between the bay and "cordilheira" (P3) has a much thicker E horizon, deeper solum and less distinctive mottles or nodules than the others (Table 4).

The colors are gray to dark brown in the A horizons, brown or black in B and pale in C. Based on the color criteria and presence of iron nodules, according to the SiBCS (Santos et al., 2018), the B horizons were identified in the field as spodic, with black to dark brown colors of $\mathrm{Bh}(\mathrm{c})$ or $\mathrm{Bhs}(\mathrm{c})$ horizons and $\mathrm{Bs}(\mathrm{c})$ with at least one color hue $5 \mathrm{YR}$ or 10YR, values 3 or 4 and chromas 4 or 6 (Table 4), except for the Btgn horizon of P3, which has a green and black variegated color. The eluvial horizons of the P3 profile are dark yellowish brown and yellowish-brown.

In the P3 and P4 profiles, the smooth transitions between the horizons indicate the dominant upward vertical flow of the water table (Figures $3 \mathrm{c}$ and $3 \mathrm{~d}$ ). On the other hand, the predominantly wavy or broken transitions between horizons in P1 and P2 suggest a greater lateral contribution to the water flow at this intermediate transect points (Figures $3 a$ and $3 b$ ).

The surface horizons have a weak, small to medium, granular structure, influenced by the content of organic matter and roots of the grass vegetation, while $B, C$ and $E$ horizons have no aggregates, except for Bstc of $\mathrm{P} 2$, which has a weak to moderate structure of small to medium subangular blocks (Table 4).

The mottles are black and yellowish-brown, and reddish brown or yellowish red mottles are due to oxide precipitation and nodule formation, respectively, of $\mathrm{Mn}$ and $\mathrm{Fe}$, mainly in $B$ horizons (Table 4, Figure 4). All profiles have small to large, irregularly shaped Fe and $\mathrm{Mn}$ nodules (Table 4). In bay soils (P1, P2 and P4), the nodules are mainly in the $B$ horizons, but there are also isolated large nodules in the $C$ horizon of P1 and P2 (Figure 4), while $\mathrm{P} 3$ has nodules in the $\mathrm{E}$ horizon. The nodule quantity was identified as very low or low in most of the horizons, with exception of the Bsc horizon of profile P4, in which nodules are frequent (Table 4). It is noteworthy that the nodules were very hard and could not be broken by hand. However, in the laboratory, during the preparation of the fine earth fraction, most of them were broken up, so that the gravel content observed in the particle-size analysis does not reflect the quantity of nodules observed in the field.

Profiles $\mathrm{P} 1$ and $\mathrm{P} 2$ contain coarse gravel and/or fine and medium gravel in all B horizons, except for the Bsc (P1) and Bh (P2) horizons, which contain Fe and Mn nodules (Table 5). The granulometry is dominated by the sand fraction, consequently, the main textural class is sandy, with exception of the Bstc horizon in P2 and the Btgn horizon in P3, which is loamy sand (Table 5 ). Among the sand fractions, analysis showed a greater participation of fine sand, followed by medium sand (Table 5 ).

There was an absolute increase of clay contents in the B horizons (Table 5), except in P1, located in a flat relief that does not favor clay removal from the surface horizons or translocation to subsurface horizons. The occurrence of any lithological discontinuity, caused particularly by sediment deposition, was evaluated, and no significant variation was observed between the fine earth fractions along the horizons of any soil profile (Table 5).

\section{Chemical attributes, pedogenetic oxides and elemental composition}

The values of $\mathrm{pH}\left(\mathrm{H}_{2} \mathrm{O}\right)$ are equal or greater than 6.0 in most horizons and they increase with depth (Table 6). The $\mathrm{pH}(\mathrm{KCl})$ values, which are lower than the $\mathrm{pH}\left(\mathrm{H}_{2} \mathrm{O}\right)$ for all horizons, decrease from surface horizons to subsurface, and they increase in the $\mathrm{C}$ horizon (Table 6). Therefore, the $\Delta \mathrm{pH}$ values, commonly used to denote predominance of cation adsorption in the exchange complex, show more negative $\Delta \mathrm{pH}$ values in the $\mathrm{B}$ horizons than in the surface horizons (Table 6). 
Table 4. Morphology of profiles in the Lower Nhecolândia subregion of the Brazilian Pantanal, Mato Grosso do Sul

\begin{tabular}{|c|c|c|c|c|c|c|}
\hline Horizon & Layer & Structure & Dominant matrix color & Mottles & Boundary & Nodules \\
\hline & $\mathrm{m}$ & & & & & \\
\hline \multicolumn{7}{|c|}{ Profile P1 - flat relief, bay area, imperfectly drained, elevation of $80 \mathrm{~m}$} \\
\hline A & $0.00-0.12(0.10-0.13)$ & W, S/M, G & $5 Y R 3 / 1$ & $\begin{array}{l}\text { 5YR 3/4 M. Sm. Dis } \\
\text { and N 2/ F. Sm. Dis. }\end{array}$ & WC & - \\
\hline Bhsc & $\begin{array}{c}0.12(0.10-0.13)- \\
0.16(0.13-0.20)\end{array}$ & SG & $5 Y R 3 / 2$ & 5YR 3/4 M. Me. Dis. & WA & $\begin{array}{c}\mathrm{VF}, \mathrm{Sm}, \mathrm{H}, \mathrm{I}, \mathrm{Fe} \\
\text { and } \mathrm{Mn}\end{array}$ \\
\hline Bsc & $\begin{array}{c}0.16(0.13-0.20)- \\
0.27(0.26-0.29)\end{array}$ & SG & 5YR $3 / 4$ & 5YR 4/4 M. Co. Dis. & WA & $\begin{array}{l}\mathrm{VF}, \mathrm{Sm}, \mathrm{H}, \mathrm{I}, \mathrm{Fe} \\
\text { and } \mathrm{Mn}\end{array}$ \\
\hline Bhc & $\begin{array}{c}(0.24-0.33)- \\
(0.26-0.24)\end{array}$ & SG & N 2/ & - & BA & $\begin{array}{l}\text { VF, Sm and C, } \\
\mathrm{H}, \mathrm{I}, \mathrm{Fe} \text { and } \mathrm{Mn}\end{array}$ \\
\hline C & $\begin{array}{c}0.27(0.26-0.29)- \\
0.52^{+}\end{array}$ & SG & - & - & - & $\begin{array}{l}\mathrm{VF}, \mathrm{C}, \mathrm{H}, \mathrm{I}, \mathrm{Fe} \\
\text { and } \mathrm{Mn}\end{array}$ \\
\hline
\end{tabular}

Profile P2 - flat relief, bay area, imperfectly drained, elevation of $80 \mathrm{~m}$

\begin{tabular}{|c|c|c|c|c|c|c|}
\hline$A$ & $0.00-0.10(0.08-0.11)$ & W, S, G & 10YR 3/1 & - & WC & - \\
\hline $\mathrm{Bh}$ & $\begin{array}{c}0.10(0.08-0.11)- \\
0.12(0.08-0.16)\end{array}$ & SG & 10YR 3/2 & - & $\mathrm{BC}$ & - \\
\hline Bhsc & $\begin{array}{c}0.12(0.08-0.16)- \\
0.14(0.11-0.17)\end{array}$ & SG & 7.5YR $3 / 2$ & - & WC & $\begin{array}{l}\mathrm{VF}, \mathrm{Sm}, \mathrm{H}, \mathrm{I}, \mathrm{Fe} \\
\text { and } \mathrm{Mn}\end{array}$ \\
\hline Bhsc/E & $\begin{array}{c}0.14(0.11-0.17)- \\
0.23(0.17-0.30)\end{array}$ & SG & 10YR 3/2 & 10YR 4/4 F. Sm. Dis. & $\mathrm{BC}$ & $\begin{array}{l}\mathrm{VF}, \mathrm{Sm}, \mathrm{H}, \mathrm{I}, \mathrm{Fe} \\
\text { and } \mathrm{Mn}\end{array}$ \\
\hline Bstc & $\begin{array}{c}0.23(0.17-0.30)- \\
0.31(0.30-0.33)\end{array}$ & $\begin{array}{l}\text { W/M, S/M } \\
\text { SB }\end{array}$ & Var. N 2/ and 10YR 3/4 & - & WC & $\begin{array}{l}\mathrm{VF}, \mathrm{Sm}, \mathrm{H}, \mathrm{I}, \mathrm{Fe} \\
\text { and } \mathrm{Mn}\end{array}$ \\
\hline Bhc & $\begin{array}{c}0.31(0.30-0.33)- \\
0.37(0.36-0.38)\end{array}$ & SG & 10YR 2/1 & & WC & $\begin{array}{c}\mathrm{F}, \mathrm{Sm}, \mathrm{H}, \mathrm{I}, \mathrm{Fe} \\
\text { and } \mathrm{Mn}\end{array}$ \\
\hline $\mathrm{C}$ & $\begin{array}{c}0.37(0.36-0.38)- \\
0.55^{+}\end{array}$ & SG & 10YR 8/1 & N 2/ F. Me. P & & $\begin{array}{l}\mathrm{VF}, \mathrm{C}, \mathrm{H}, \mathrm{I}, \mathrm{Fe} \\
\text { and } \mathrm{Mn}\end{array}$ \\
\hline
\end{tabular}

Profile P3 - flat relief, transition between bay and "cordilheira", imperfectly drained, elevation of $82 \mathrm{~m}$

\begin{tabular}{|c|c|c|c|c|c|c|}
\hline A1 & $0.00-0.10$ & $W, S / M, G$ & 10YR 3/1 & - & $\mathrm{SC}$ & - \\
\hline$A 2$ & $0.10-0.18$ & W, S, G & 10YR 4/1 & - & $\mathrm{SA}$ & - \\
\hline E1 & $0.18-0.28$ & SG & 7.5YR 3/4 & - & $\mathrm{SC}$ & $\begin{array}{c}\mathrm{VF}, \mathrm{Sm}, \mathrm{H}, \mathrm{I}, \mathrm{Fe} \\
\text { and } \mathrm{Mn}\end{array}$ \\
\hline E2 & $0.18-0.45$ & SG & 10YR 5/4 & - & - & $\begin{array}{l}\mathrm{VF}, \mathrm{Sm}, \mathrm{H}, \mathrm{I}, \mathrm{Fe} \\
\text { and } \mathrm{Mn}\end{array}$ \\
\hline $\mathrm{Bh}$ & $0.85-1.05$ & - & N 2/ & - & - & - \\
\hline Btgn & $1.05-1.15^{+}$ & - & Var. N 2/ and 5GY 5/2 & - & - & - \\
\hline \multicolumn{7}{|c|}{ Profile P4 - flat relief, bay area, imperfectly drained, elevation of $80 \mathrm{~m}$} \\
\hline A & $0.00-0.065$ & W, S/M, G & 10YR 3/3 & 5YR 5/8 C. Sm. Dis. & $\mathrm{SC}$ & - \\
\hline Bhs & $0.065-0.09$ & SG & Var. 7.5YR 2.5/3 and 7.5YR 3/1 & - & SA & - \\
\hline Bs1 & $0.09-0.145$ & SG & 7.5YR 3/4 & - & $\mathrm{SC}$ & $\begin{array}{l}\mathrm{VF}, \mathrm{Sm}, \mathrm{H}, \mathrm{I}, \mathrm{Fe} \\
\text { and } \mathrm{Mn}\end{array}$ \\
\hline Bs2 & $0.145-0.205$ & SG & 10YR 4/6 & - & $\mathrm{SC}$ & $\begin{array}{c}\mathrm{VF}, \mathrm{Sm}, \mathrm{H}, \mathrm{I}, \mathrm{Fe} \\
\text { and } \mathrm{Mn}\end{array}$ \\
\hline Bsc & $0.205-0.27$ & SG & Var. 5YR 3/4 and 5YR 3/3 & - & SA & $\begin{array}{c}\mathrm{Fr}, \mathrm{Sm} \text { and } \mathrm{C}, \\
\mathrm{H}, \mathrm{I}, \mathrm{Fe} \text { and } \mathrm{Mn}\end{array}$ \\
\hline C & $0.27-0.45^{+}$ & SG & 10YR 6/4 & 10YR 4/4 F/C Me. Dis. & & - \\
\hline
\end{tabular}

Horizon subscripts according to Santos et al. (2015) where the letter $\mathrm{h}$ correspond to accumulation of illuvial organic matter, $\mathrm{s}$ correspond to accumulation of illuvial Al and Fe oxides and c correspond to concretion and nodules. In WRB Guidelines for Soil Description (Jahn et al., 2006), letters c and s have the same description as Santos et al. (2015), but letter $\mathrm{h}$ stands for organic matter accumulation, which, in this case, may occur in surface horizons or in subsurface horizons through illuviation. Structure: (i) development degree: W - weak and M - moderate; (ii) size: S - small and M - medium; (iii) shape: G - Granular, SB - Subangular blocks and SG - single grains; Color: Var - variegated; Mottles: (i) Quantity: F - few, C - common and M - many; (ii) Size: Sm - Small, Me - Medium and Co - Coarse; (iii) Contrast: Dis - Distinct and Pro - Prominent; Boundary: (i) Topography: S - smooth; W - wavy and B - broken; (ii) Distinctness: C - clear, A - abrupt. Water table level: P1 - 0.52 m; P2 - 0.55 m; P3 - 0.45 m; P4 - 0.43 m. Nodules: (i) Quantity: VF - Very few (less than $5 \%$ of volume); F - Few ( 5 to $15 \%$ of volume); Fr - Frequent ( 15 to $40 \%$ of volume); (ii) Size: Sm - Small (diameter $<1 \mathrm{~cm}$ ); C - Coarse (diameter >1 cm); (iii) Shape: I - Irregular; (iv) Hardness: H - Hard; (v) Nature: Iron and manganese. There was no presence of carbonates in any profile. Coarse and medium gravel are composed of Fe and/or Mn nodules in P1 and P2. The Btgn horizon was sampled (auger) and the structure could not be evaluated. However, sampling occurred at the same location as the MS-1 profile described in the 10th Brazilian Soil Classification and Correlation Meeting (RCC, 2012), so that the authors decided to assume the identification of this event. 

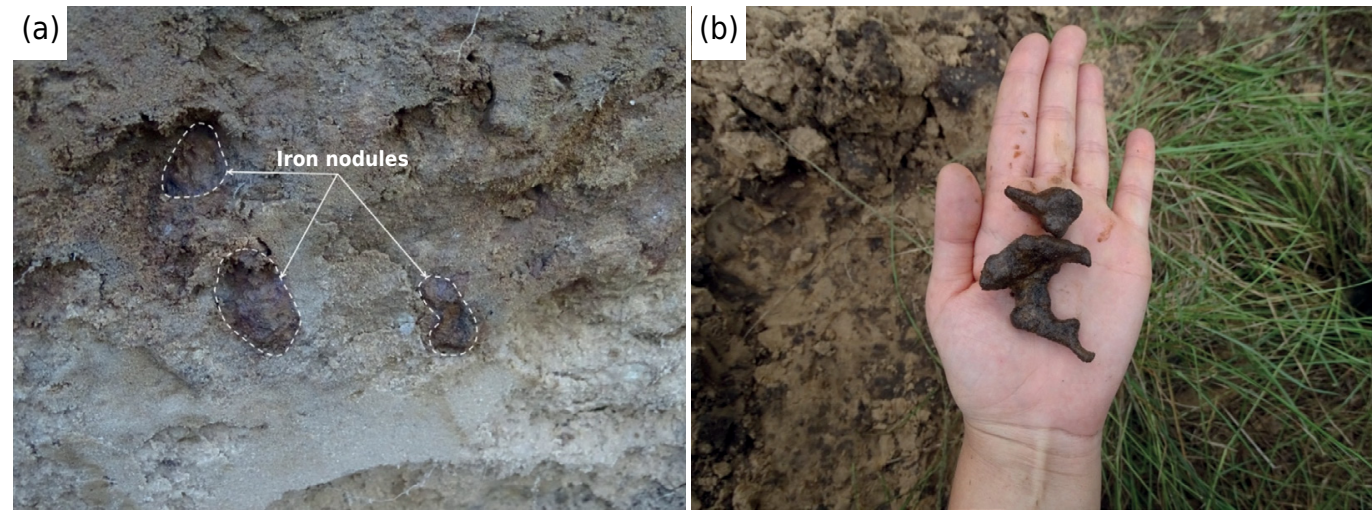

Figure 4. Iron nodules in detail in the $\mathrm{C}$ horizon of profile P1 (a) and manganese nodules in the C horizon of profile P2 (b).

The cation exchange complex shows the greatest contribution of $\mathrm{Ca}^{2+}$ and $\mathrm{Mg}^{2+}$, while $\mathrm{Al}^{3+}$ was not detected or at very low quantities (Table 6). The distribution of $\mathrm{Ca}^{2+}$ and $\mathrm{Mg}^{2+}$ contents, in general, followed organic carbon and clay, in the A and B horizons, and varied with the development degree of the profile. In the bay soils, $\mathrm{K}^{+}$and $\mathrm{Na}^{+}$ accumulated mainly in the $\mathrm{B}$ horizon, immediately above the $\mathrm{C}$ horizon; while in $\mathrm{P} 3$, they were concentrated in the horizon overlying Btgn (Table 6).

As similarly observed for exchangeable cations, the $S$ values were high (above $1.0 \mathrm{cmol}_{c} \mathrm{~kg}^{-1}$ ) in most horizons except Bsc (P1), A2 (P3), Bs1 and Bs2 (P4) (Table 6). In general, the S values in all profiles varied according to the clay and organic carbon content and with depth. The V\% values exceeded $50 \%$ in all horizons of P1, P2 and P3, except in Bhsc of $\mathrm{P} 1$ and $\mathrm{C}$ of P4 (Table 6).

The exchangeable sodium percentage (ESP) increases with depth, with maximum values of $24 \%$ in $\mathrm{P} 1$ and $\mathrm{P} 4,28 \%$ in $\mathrm{P} 2$ and $13 \%$ in P3 (Table 6). Consequently, according to SiBCS (Santos et al., 2018), the Bhsc, Bhsc /E, Bstc, and Bhc horizons of P2, and $\mathrm{Bh}$ and Btgn horizons of P3 fit the criteria for a solodic character; and horizons $\mathrm{C}$ of P1, P2 and P4 have a sodic character. In this sense, the surface horizons have slightly higher soluble $\mathrm{K}^{+}$and $\mathrm{Na}^{+}$contents than the $\mathrm{B}$ horizons (Table 6 ). In the same way, electrical conductivity decreases with depth in the order: A horizons $>0.8 \mathrm{mS} \mathrm{cm}^{-1} 25^{\circ} \mathrm{C}$, B horizons - $<0.6 \mathrm{mS} \mathrm{cm}^{-1} 25^{\circ} \mathrm{C}$ and $\mathrm{C}$ horizons $-<0.2 \mathrm{~ms} \mathrm{~cm}^{-1} 25^{\circ} \mathrm{C}$ (Table 6).

In general, the organic carbon (C org) contents were low and decreased with depth, except in the three $B$ horizons, where contents were higher in relation to the overlying horizon (Table 6), namely: $0.4 \mathrm{~g} \mathrm{~kg}^{-1}$ in the Bhs/E horizon in relation to horizon Bhsc of profile $\mathrm{P} 2 ; 1.0 \mathrm{~g} \mathrm{~kg}^{-1}$ in the Bh horizon in relation to horizon E2 of $\mathrm{P} 3$, and $0.6 \mathrm{~g} \mathrm{~kg}^{-1}$ in the Bs2 horizon in relation to horizon Bs1 of P4.

The predominant chemical elements in the fine earth fraction, extracted by sulfuric acid and expressed as oxides, were $\mathrm{SiO}_{2}$ and $\mathrm{Fe}_{2} \mathrm{O}_{3}$, with the exception of $\mathrm{P} 3$, where the $\mathrm{Al}_{2} \mathrm{O}_{3}$ contents were higher than $\mathrm{Fe}_{2} \mathrm{O}_{3}$ (Table 7). The $\mathrm{SiO}_{2}$ contents were mostly above $800 \mathrm{~g} \mathrm{~kg}^{-1}$ and decreased in depth. On the other hand, $\mathrm{Fe}_{2} \mathrm{O}_{3}$ contents followed the clay distribution in depth, where the values in the horizons $\mathrm{Bs}(\mathrm{c})$ and $\mathrm{Bhs}(\mathrm{c})$ were higher than in the other horizons. For $\mathrm{Fe}_{2} \mathrm{O}_{3}$, the $\mathrm{Al}_{2} \mathrm{O}_{3}$ contents were higher in the $\mathrm{B}$ horizons (Table 7). Comparing the difference of $\mathrm{Fe}_{2} \mathrm{O}_{3}$ and $\mathrm{Al}_{2} \mathrm{O}_{3}$ obtained by XRF and sulfuric acid extraction, $\mathrm{Fe}_{2} \mathrm{O}_{3}$ and $\mathrm{Al}_{2} \mathrm{O}_{3}$ contents increased in the $\mathrm{B}$ horizons, except in P1 (Table 7).

The $\mathrm{TiO}_{2}$ contents were equally distributed along the soil profile, except in the Btgn horizon of $\mathrm{P} 3$, and are therefore not an indicator of any lithological discontinuity (Table 7). Both $\mathrm{MnO}_{2}$ and $\mathrm{P}_{2} \mathrm{O}_{5}$ contents were lower than $1.0 \mathrm{~g} \mathrm{~kg}^{-1}$ in most horizons (Table 7). The $\mathrm{MnO}_{2}$ contents were higher in the $\mathrm{B}$ horizons with presence of nodules (Bhsc and BsC) 
Table 5. Particle-size distribution of profiles in the Lower Nhecolândia subregion of the Brazilian Pantanal, Mato Grosso do Sul

\begin{tabular}{|c|c|c|c|c|c|c|c|c|c|c|c|c|}
\hline \multirow[b]{2}{*}{ Horizon } & \multicolumn{3}{|c|}{ Fractions of the total sample } & \multicolumn{9}{|c|}{ Granulometric composition of fine earth } \\
\hline & $\begin{array}{l}\text { Coarse } \\
\text { gravel }\end{array}$ & $\begin{array}{c}\text { Fine and } \\
\text { medium gravel }\end{array}$ & Fine earth & $\begin{array}{l}\text { Very coarse } \\
\text { sand }\end{array}$ & $\begin{array}{l}\text { Coarse } \\
\text { sand }\end{array}$ & $\begin{array}{l}\text { Medium } \\
\text { sand }\end{array}$ & $\begin{array}{l}\text { Fine } \\
\text { sand }\end{array}$ & $\begin{array}{l}\text { Very fine } \\
\text { sand }\end{array}$ & $\begin{array}{l}\text { Total } \\
\text { sand }\end{array}$ & Silt & Clay & Texture \\
\hline & & & 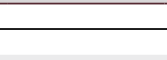 & 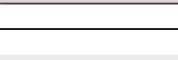 & $\mathrm{g} \mathrm{kg}$ & 1 & 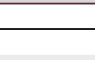 & 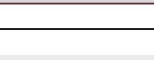 & & & & \\
\hline \multicolumn{13}{|c|}{ Profile P1 - flat relief, bay area, imperfectly drained, elevation of $80 \mathrm{~m}$} \\
\hline A & 0 & 0 & 1000 & 11 & 29 & 457 & 429 & 39 & 965 & 22 & 12 & Sand \\
\hline Bhsc & 0 & 36 & 964 & 16 & 29 & 354 & 534 & 30 & 963 & 21 & 16 & Sand \\
\hline Bsc & 0 & 0 & 1000 & 24 & 25 & 271 & 602 & 40 & 962 & 17 & 21 & Sand \\
\hline Bhc & 12 & 20 & 968 & 3 & 11 & 317 & 597 & 36 & 963 & 16 & 21 & Sand \\
\hline C & 0 & 0 & 1000 & 0 & 9 & 218 & 694 & 63 & 985 & 6 & 9 & Sand \\
\hline \multicolumn{13}{|c|}{ Profile P2 - flat relief, bay area, imperfectly drained, elevation of $80 \mathrm{~m}$} \\
\hline A & 0 & 0 & 1000 & 10 & 16 & 285 & 603 & 43 & 958 & 15 & 27 & Sand \\
\hline $\mathrm{Bh}$ & 0 & 0 & 1000 & 6 & 26 & 209 & 655 & 56 & 952 & 10 & 38 & Sand \\
\hline Bhsc & 0 & 23 & 977 & 5 & 22 & 235 & 615 & 72 & 950 & 12 & 38 & Sand \\
\hline Bhsc/E & 0 & 32 & 968 & 12 & 29 & 238 & 605 & 45 & 929 & 7 & 64 & Sand \\
\hline Bstc & 0 & 18 & 982 & 11 & 56 & 248 & 502 & 59 & 877 & 2 & 120 & $\begin{array}{l}\text { Loamy } \\
\text { sand }\end{array}$ \\
\hline Bhc & 0 & 53 & 947 & 4 & 40 & 258 & 594 & 45 & 941 & 9 & 49 & Sand \\
\hline C & 0 & 0 & 1000 & 0 & 10 & 168 & 715 & 84 & 977 & 11 & 11 & Sand \\
\hline \multicolumn{13}{|c|}{ Profile P3 - flat relief, transition between bay and "cordilheira", imperfectly drained, elevation of $82 \mathrm{~m}$} \\
\hline Al & 0 & 0 & 1000 & 11 & 19 & 340 & 534 & 57 & 961 & 22 & 17 & Sand \\
\hline A2 & 0 & 0 & 1000 & 0 & 7 & 204 & 702 & 62 & 975 & 11 & 14 & Sand \\
\hline E1 & 0 & 0 & 1000 & 0 & 10 & 187 & 721 & 61 & 980 & 10 & 11 & Sand \\
\hline E2 & 0 & 0 & 1000 & 0 & 9 & 197 & 723 & 52 & 982 & 8 & 10 & Sand \\
\hline $\mathrm{Bh}$ & 0 & 0 & 1000 & 0 & 7 & 163 & 711 & 75 & 956 & 7 & 37 & Sand \\
\hline Btgn & 0 & 0 & 1000 & 0 & 15 & 148 & 673 & 55 & 892 & 9 & 99 & $\begin{array}{l}\text { Loamy } \\
\text { sand }\end{array}$ \\
\hline \multicolumn{13}{|c|}{ Profile P4 - flat relief, bay area, imperfectly drained, elevation of $80 \mathrm{~m}$} \\
\hline A & 0 & 0 & 1000 & 9 & 23 & 320 & 580 & 32 & 964 & 10 & 26 & Sand \\
\hline Bhs & 0 & 0 & 1000 & 11 & 24 & 236 & 639 & 51 & 960 & 11 & 29 & Sand \\
\hline Bs1 & 0 & 0 & 1000 & 19 & 21 & 249 & 611 & 51 & 951 & 13 & 35 & Sand \\
\hline Bs2 & 0 & 0 & 1000 & 18 & 26 & 336 & 529 & 44 & 954 & 5 & 42 & Sand \\
\hline Bsc & 0 & 0 & 1000 & 59 & 39 & 194 & 587 & 50 & 929 & 10 & 61 & Sand \\
\hline C & 0 & 0 & 1000 & 1 & 12 & 264 & 641 & 66 & 983 & 7 & 9 & Sand \\
\hline
\end{tabular}

The Bsc horizons of the P1 profile and Bsc of the P4 profile presented gravel in an amount less than $1 \%$, however, the authors chose to keep the field description with the subscript " $c$ " because extremely hard and unbreakable nodules were identified with the use of hands in the field, but which fell apart after the preparation of the fine earth fraction.

and in Btgn. On the other hand, the $\mathrm{P}_{2} \mathrm{O}_{5}$ values in the Bsc horizons were higher than in the other horizons (Table 7).

In all soil profiles, there was an increase of $\mathrm{Fe}_{o}$ and $\mathrm{Fe}_{d}$ contents in the $\mathrm{B}$ horizons in relation to the surface horizons, except for $\mathrm{Fe}_{0}$ in P1 (Table 7). The $\mathrm{Fe}_{\mathrm{o}} / \mathrm{Fe}_{\mathrm{d}}$ ratio was predominantly lower than or equal to 0.3 in $B$ horizons with nodules, while in the other horizons this ratio was higher than or equal to 0.5 . These data indicate that in $B$ horizons with nodules there is a greater participation of more crystalline forms of Fe oxides, whereas in the other horizons, the less crystalline forms predominate.

The aluminum values expressed as $\mathrm{Al}_{0}$, presumably in a weakly crystalline form, were less than or equal to $0.2 \mathrm{~g} \mathrm{~kg}^{-1}$ (Table 7). In the soil profiles near the bay area, the $\mathrm{Al}_{\circ}$ value in the B horizons was the same or decreased with depth, except in the Bstc horizon of 
Table 6. Chemical attributes of profiles in the Lower Nhecolândia subregion of the Brazilian Pantanal, Mato Grosso do Sul

\begin{tabular}{|c|c|c|c|c|c|c|c|c|c|c|c|c|c|c|c|c|c|}
\hline \multirow{2}{*}{ Hor. } & \multicolumn{2}{|c|}{ pH } & \multirow{2}{*}{$\Delta \mathrm{pH}$} & \multicolumn{7}{|c|}{ Cationic complex } & \multirow{2}{*}{$\mathbf{v}$} & \multirow{2}{*}{ ESP } & \multirow{2}{*}{ C org } & \multicolumn{2}{|c|}{ Saturation extract } & \multicolumn{2}{|c|}{ Soluble salts } \\
\hline & $\mathrm{H}_{2} \mathrm{O}$ & $\mathrm{KCl}$ & & $\mathrm{Ca}^{2+}$ & $\mathbf{M g}^{2+}$ & $\mathbf{K}^{+}$ & $\mathrm{Na}^{+}$ & $\mathbf{s}$ & $\mathrm{Al}^{3+}$ & $\mathbf{T}$ & & & & $\mathrm{H}_{2} \mathrm{O}$ & EC & $\mathbf{K}^{+}$ & $\mathrm{Na}^{+}$ \\
\hline & & & & \multicolumn{9}{|c|}{$\longrightarrow \mathrm{cmol}_{\mathrm{c}} \mathrm{kg}^{-1} \longrightarrow \%-$} & $\mathrm{g} \mathrm{kg}^{-1}$ & $\%$ & $\mathrm{mS} \mathrm{cm}{ }^{-1} 25^{\circ} \mathrm{C}$ & \multicolumn{2}{|c|}{$\mathrm{cmol}_{\mathrm{c}} \mathrm{kg}^{-1}$} \\
\hline \multicolumn{18}{|c|}{ Profile P1 - flat relief, bay area, imperfectly drained, elevation of $80 \mathrm{~m}$} \\
\hline A & 6.0 & 5.2 & -0.8 & 1.8 & 0.3 & 0.32 & 0.00 & 2.3 & 0.0 & 4.3 & 53 & 0 & 6.2 & 29 & 0.8 & 0.06 & 0.06 \\
\hline Bhsc & 5.5 & 4.4 & -1.1 & 0.9 & 0.1 & 0.17 & 0.07 & 1.2 & 0.1 & 3.0 & 39 & 2 & 2.1 & 26 & 0.3 & 0.02 & 0.03 \\
\hline Bsc & 5.9 & 5.0 & -0.9 & 0.6 & 0.1 & 0.10 & 0.05 & 0.9 & 0.0 & 1.6 & 55 & 3 & 0.8 & 23 & 0.3 & 0.01 & 0.02 \\
\hline Bhc & 5.7 & 4.3 & -1.4 & 1.1 & 0.2 & 0.26 & 0.08 & 1.6 & 0.1 & 2.3 & 69 & 4 & 0.5 & 20 & 0.3 & 0.02 & 0.02 \\
\hline C & 6.0 & 4.7 & -1.3 & 0.0 & 0.0 & 0.04 & 0.02 & 0.1 & 0.0 & 0.1 & 100 & 24 & 0.2 & 20 & 0.1 & 0.00 & 0.01 \\
\hline \multicolumn{18}{|c|}{ Profile P2 - flat relief, bay area, imperfectly drained, elevation of $80 \mathrm{~m}$} \\
\hline A & 6.6 & 5.6 & -1.0 & 1.9 & 0.5 & 0.31 & 0.20 & 2.7 & 0.0 & 3.9 & 70 & 5 & 5.4 & 26 & 0.9 & 0.05 & 0.11 \\
\hline $\mathrm{Bh}$ & 6.3 & 4.8 & -1.5 & 1.5 & 0.5 & 0.46 & 0.22 & 2.6 & 0.0 & 4.4 & 59 & 5 & 3.3 & 23 & 0.6 & 0.03 & 0.08 \\
\hline Bhsc & 6.6 & 5.0 & -1.6 & 1.2 & 0.4 & 0.36 & 0.25 & 2.1 & 0.0 & 3.1 & 68 & 8 & 2.1 & 23 & 0.5 & 0.02 & 0.08 \\
\hline Bhsc/E & 6.6 & 5.0 & -1.6 & 2.0 & 0.8 & 0.54 & 0.40 & 3.6 & 0.0 & 5.3 & 68 & 8 & 2.5 & 25 & 0.6 & 0.03 & 0.10 \\
\hline Bstc & 7.0 & 5.3 & -1.7 & 6.9 & 2.9 & 0.64 & 1.20 & 11.5 & 0.0 & 13.3 & 87 & 9 & 2.1 & 45 & 0.2 & 0.01 & 0.05 \\
\hline Bhc & 7.2 & 5.4 & -1.8 & 2.6 & 0.9 & 0.47 & 0.49 & 4.5 & 0.0 & 5.2 & 86 & 9 & 0.8 & 31 & 0.1 & 0.01 & 0.03 \\
\hline C & 7.2 & 5.7 & -1.5 & 0.1 & 0.1 & 0.08 & 0.10 & 0.4 & 0.0 & 0.4 & 100 & 28 & 0.1 & 21 & 0.2 & 0.01 & 0.03 \\
\hline \multicolumn{18}{|c|}{ Profile P3 - flat relief, transition between bay and "cordilheira", imperfectly drained, elevation of $82 \mathrm{~m}$} \\
\hline Al & 7.5 & 6.8 & -0.7 & 2.9 & 0.6 & 0.14 & 0.02 & 3.7 & 0.0 & 4.1 & 90 & 0 & 7.7 & 28 & 0.8 & 0.03 & 0.01 \\
\hline A2 & 5.5 & 4.8 & -0.7 & 0.7 & 0.1 & 0.09 & 0.01 & 0.9 & 0.0 & 1.6 & 55 & 1 & 1.1 & 22 & 0.5 & 0.02 & 0.01 \\
\hline E1 & 6.9 & 6.2 & -0.7 & 0.4 & 0.1 & 0.07 & 0.01 & 0.6 & 0.0 & 0.6 & 100 & 2 & 0.2 & 22 & 0.4 & 0.01 & 0.01 \\
\hline E2 & 6.6 & 5.7 & -0.9 & 0.2 & 0.1 & 0.07 & 0.01 & 0.4 & 0.0 & 0.4 & 100 & 3 & 0.7 & 22 & 0.3 & 0.01 & 0.01 \\
\hline $\mathrm{Bh}$ & 7.9 & 6.3 & -1.6 & 1.8 & 0.5 & 0.48 & 0.23 & 3.0 & 0.0 & 3.3 & 91 & 7 & 1.7 & 32 & 0.1 & 0.01 & 0.03 \\
\hline Btgn & 7.7 & 5.7 & -2.0 & 2.1 & 0.6 & 1.60 & 0.72 & 5.0 & 0.0 & 5.7 & 88 & 13 & 0.1 & 32 & 0.2 & 0.01 & 0.04 \\
\hline \multicolumn{18}{|c|}{ Profile P4 - flat relief, bay area, imperfectly drained, elevation of $80 \mathrm{~m}$} \\
\hline A & 5.8 & 5.1 & -0.7 & 1.6 & 0.2 & 0.15 & 0.05 & 1.9 & 0.0 & 4.0 & 48 & 1 & 5.0 & 28 & 0.9 & 0.03 & 0.03 \\
\hline Bhs & 5.8 & 4.6 & -1.2 & 0.7 & 0.1 & 0.10 & 0.09 & 1.0 & 0.0 & 2.7 & 36 & 3 & 2.7 & 25 & 0.2 & 0.01 & 0.03 \\
\hline Bs1 & 6.2 & 5.1 & -1.1 & 0.5 & 0.1 & 0.07 & 0.05 & 0.7 & 0.0 & 1.7 & 40 & 3 & 1.4 & 23 & 0.2 & 0.01 & 0.02 \\
\hline Bs2 & 6.2 & 4.9 & -1.3 & 0.5 & 0.1 & 0.08 & 0.07 & 0.8 & 0.0 & 2.3 & 34 & 3 & 2.0 & 24 & 0.2 & 0.01 & 0.02 \\
\hline Bsc & 6.3 & 5.2 & -1.1 & 0.7 & 0.1 & 0.11 & 0.07 & 1.0 & 0.0 & 2.7 & 36 & 3 & 1.6 & 27 & 0.2 & 0.01 & 0.02 \\
\hline C & 6.5 & 5.2 & -1.3 & 0.0 & 0.0 & 0.04 & 0.02 & 0.1 & 0.0 & 0.1 & 100 & 24 & 0.1 & 24 & 0.1 & 0.00 & 0.01 \\
\hline
\end{tabular}

Hor.: horizon; S: sum of bases; T: cation exchange capacity at $\mathrm{pH} 7.0$; V: base saturation; ESP: exchangeable sodium percentage $=(\mathrm{Na} / \mathrm{T}) \times 100$; C org: organic carbon; EC: electrical conductivity.

$\mathrm{P} 2$, which was $0.1 \mathrm{~g} \mathrm{~kg}^{-1}$ higher in the A horizon (Table 7). In the Bh horizon of P3, on the other hand, it was $0.1 \mathrm{~g} \mathrm{~kg}^{-1}$ and $0.0 \mathrm{~g} \mathrm{~kg}^{-1}$ in the overlying eluvial horizon.

There was an increase with depth in $\mathrm{Mn}$ contents in the weakly crystalline forms $\left(\mathrm{Mn}_{0}\right)$, and in the strong and weakly crystalline forms $\left(\mathrm{Mn}_{\mathrm{d}}\right)$ in all profiles, except in P1 (Table 7). In P3, this increase was observed in the Btgn horizon, with higher clay content and, consequently, relatively lower permeability, which favors Mn accumulation.

\section{Carbon and elemental composition in nodules}

In horizons with spodic features, $\mathrm{C}$ org in the nodules varied from 1.5 to $3.0 \mathrm{~g} \mathrm{~kg}^{-1}$ and was predominantly higher or very close to the value observed in the fine earth of the respective horizons (Table 8). Organic carbon contents in the eluvial horizons of P3 were not detectable. However, by the applied method, Mn competes with carbon in the oxidation with $\mathrm{K}_{2} \mathrm{Cr}_{2} \mathrm{O}_{7}\left(0.0667 \mathrm{~mol} \mathrm{~L}^{-1}\right)$; thus, the $\mathrm{C}$ org content might be underestimated, as suggested by the high Mn contents (Table 8). Total carbon (TC) in the nodules $\left(2.7-7.8 \mathrm{~g} \mathrm{~kg}^{-1}\right.$ ), 
determined with a Perkin Elmer PE-2400 CHNSO elemental analyzer, exceeded the C org values determined routinely by wet oxidation (Table 8 ). This observation emphasizes the participation of organic material in the composition of the nodules.

The predominant oxides in the nodules of the $\mathrm{B}$ horizons were $\mathrm{SiO}_{2}$ and $\mathrm{Fe}_{2} \mathrm{O}_{3}$, while in the nodules of the $\mathrm{E}$ horizons of $\mathrm{P} 3, \mathrm{SiO}_{2}$ and $\mathrm{MnO}_{2}$ oxides prevailed (Table 8). It is noteworthy that nodules in the $\mathrm{E}$ horizons of $\mathrm{P} 3$ have relatively higher $\mathrm{SiO}_{2}$ contents (around $850 \mathrm{~g} \mathrm{~kg}^{-1}$ ) than those in the B horizons (except for P1 - Bhc, $763.5 \mathrm{~g} \mathrm{~kg}^{-1}$ or less).

The $\mathrm{Al}_{2} \mathrm{O}_{3}$ and $\mathrm{TiO}_{2}$ contents were relatively close to those observed in the fine earth, therefore, there was no accumulation of these elements in the nodules (Table 8). The $\mathrm{Fe}_{2} \mathrm{O}_{3}, \mathrm{MnO}_{2}$ and $\mathrm{P}_{2} \mathrm{O}_{5}$ contents in all nodules were higher than in the fine earth of their respective horizons, which indicates the accumulation of these elements in the nodules; while the $\mathrm{SiO}_{2}$ contents were much lower in the nodules than in the fine earth (Table 8). In the nodules of $\mathrm{B}$ horizons, the $\mathrm{Fe}_{2} \mathrm{O}_{3}, \mathrm{MnO}_{2}$ and $\mathrm{P}_{2} \mathrm{O}_{5}$ contents varied, respectively,

Table 7. Oxides obtained by XRF, pedogenetic oxides, $\mathrm{Al}_{2} \mathrm{O}_{3}$ and $\mathrm{Fe}_{2} \mathrm{O}_{3}$ (difference between XRF and sulfuric acid extraction) of soil profiles in the Lower Nhecolândia subregion of the Brazilian Pantanal, Mato Grosso do Sul

\begin{tabular}{|c|c|c|c|c|c|c|c|c|c|c|c|c|c|c|}
\hline \multirow{2}{*}{ Horizon } & \multicolumn{6}{|c|}{ XRF } & \multirow{2}{*}{$\mathrm{Fe}_{\mathrm{o}}$} & \multirow{2}{*}{$\mathbf{A l}_{\circ}$} & \multirow{2}{*}{$M n_{0}$} & \multirow{2}{*}{$\mathrm{Fe}_{\mathrm{d}}$} & \multirow{2}{*}{$\mathbf{M n}_{\mathrm{d}}$} & \multirow{2}{*}{$\mathrm{Fe}_{\mathrm{o}} / \mathrm{Fe}_{\mathrm{d}}$} & \multicolumn{2}{|c|}{ XRF - sulfuric acid extraction } \\
\hline & $\mathrm{SiO}_{2}$ & $\mathrm{Al}_{2} \mathrm{O}_{3}$ & $\mathrm{Fe}_{2} \mathrm{O}_{3}$ & $\mathrm{TiO}_{2}$ & $\mathrm{MnO}_{2}$ & $\mathbf{P}_{2} \mathbf{O}_{5}$ & & & & & & & $\mathrm{Al}_{2} \mathrm{O}_{3}$ & $\mathrm{Fe}_{2} \mathrm{O}_{3}$ \\
\hline & & & & & $-\mathrm{gk}$ & $\mathrm{kg}^{-1}$ & & & & & & & \multicolumn{2}{|c|}{$\mathrm{g} \mathrm{kg}^{-1}$} \\
\hline \multicolumn{15}{|c|}{ Profile P1 - flat relief, bay area, imperfectly drained, elevation of $80 \mathrm{~m}$} \\
\hline A & 975.8 & 12.0 & 24.8 & 1.2 & 0.9 & 0.6 & 13.3 & 0.1 & 0.9 & 14.9 & 0.6 & 0.9 & 9.0 & 1.8 \\
\hline Bhsc & 969.4 & 11.9 & 40.0 & 1.2 & 0.6 & 0.4 & 10.1 & 0.1 & 0.4 & 31.2 & 0.4 & 0.3 & 9.9 & 7.0 \\
\hline Bsc & 927.0 & 11.5 & 75.5 & 1.2 & 0.5 & 1.0 & 4.9 & 0.1 & 0.3 & 65.0 & 0.3 & 0.1 & 7.5 & 3.5 \\
\hline Bhc & 987.3 & 16.9 & 17.0 & 1.2 & 0.2 & 0.3 & 3.1 & 0.1 & 0.2 & 7.5 & 0.1 & 0.4 & 7.9 & 1.0 \\
\hline C & 1025.5 & 9.0 & 1.5 & 0.9 & 0.0 & 0.2 & 0.2 & 0.0 & $<\mathrm{DL}$ & 0.8 & $<\mathrm{DL}$ & 0.3 & 7.0 & 0.0 \\
\hline \multicolumn{15}{|c|}{ Profile P2 - flat relief, bay area, imperfectly drained, elevation of $80 \mathrm{~m}$} \\
\hline A & 985.7 & 14.9 & 10.0 & 1.5 & 0.3 & 0.3 & 3.1 & 0.1 & 0.3 & 5.0 & 0.2 & 0.6 & 10.9 & 0.0 \\
\hline $\mathrm{Bh}$ & 977.8 & 19.0 & 18.5 & 1.6 & 1.3 & 0.3 & 7.1 & 0.1 & 1.3 & 8.3 & 1.0 & 0.9 & 9.0 & 1.5 \\
\hline Bhsc & 967.3 & 16.2 & 33.4 & 1.6 & 1.0 & 0.3 & 5.1 & 0.1 & 0.9 & 26.6 & 0.7 & 0.2 & 8.2 & 4.4 \\
\hline Bhsc/E & 896.7 & 19.2 & 80.3 & 1.6 & 1.7 & 0.4 & 7.8 & 0.1 & 1.1 & 61.6 & 1.3 & 0.1 & 8.2 & 11.3 \\
\hline Bstc & 766.1 & 20.7 & 174.6 & 1.4 & 2.0 & 1.3 & 16.5 & 0.2 & 1.4 & 93.4 & 1.2 & 0.2 & 5.7 & 19.6 \\
\hline Bhc & 958.7 & 19.0 & 33.1 & 1.4 & 0.5 & 0.3 & 3.2 & 0.1 & 0.4 & 12.3 & 0.3 & 0.3 & 10.0 & 2.1 \\
\hline C & 1010.1 & 11.6 & 2.5 & 1.3 & 0.1 & 0.2 & 0.6 & 0.0 & 0.0 & 0.8 & $<\mathrm{DL}$ & 0.8 & 8.6 & 0.5 \\
\hline \multicolumn{15}{|c|}{ Profile P3 - flat relief, transition between bay and "cordilheira", imperfectly drained, elevation of $82 \mathrm{~m}$} \\
\hline A1 & 986.5 & 12.8 & 3.4 & 1.4 & 0.4 & 0.3 & 0.7 & 0.1 & 0.5 & 0.7 & 0.2 & 1.0 & 8.8 & 1.4 \\
\hline A2 & 1007.9 & 11.9 & 2.5 & 1.3 & 0.3 & 0.2 & 0.3 & 0.0 & 0.3 & 0.4 & 0.1 & 0.8 & 8.9 & 0.0 \\
\hline E1 & 1014.4 & 11.5 & 2.1 & 1.2 & 0.4 & 0.2 & 0.2 & 0.0 & 0.4 & 0.3 & 0.2 & 0.7 & 8.5 & 0.1 \\
\hline E2 & 1010.1 & 11.5 & 1.8 & 1.3 & 0.1 & 0.2 & 0.1 & 0.0 & 0.1 & 0.3 & 0.1 & 0.3 & 9.5 & 0.0 \\
\hline $\mathrm{Bh}$ & 980.1 & 22.4 & 7.3 & 1.7 & 0.3 & 0.3 & 0.5 & 0.1 & 0.2 & 1.1 & 0.1 & 0.5 & 8.4 & 0.3 \\
\hline Btgn & 933.0 & 41.9 & 15.3 & 2.7 & 2.1 & 0.3 & 0.9 & 0.2 & 1.9 & 1.7 & 1.5 & 0.5 & 11.9 & 0.0 \\
\hline \multicolumn{15}{|c|}{ Profile P4 - flat relief, bay area, imperfectly drained, elevation of $80 \mathrm{~m}$} \\
\hline A & 963.6 & 11.8 & 31.4 & 1.2 & 0.7 & 0.5 & 10.6 & 0.1 & 0.6 & 23.2 & 0.5 & 0.5 & 6.8 & 7.4 \\
\hline Bhs & 956.6 & 11.6 & 44.2 & 1.3 & 0.7 & 0.4 & 10.6 & 0.1 & 0.5 & 35.0 & 0.5 & 0.3 & 7.6 & 3.2 \\
\hline Bs1 & 922.3 & 11.2 & 73.8 & 1.3 & 0.3 & 0.6 & 4.3 & 0.0 & 0.2 & 60.2 & 0.1 & 0.1 & 7.2 & 8.8 \\
\hline Bs2 & 926.6 & 11.4 & 70.4 & 1.3 & 0.4 & 0.5 & 5.3 & 0.0 & 0.2 & 57.9 & 0.2 & 0.1 & 7.4 & 2.4 \\
\hline Bsc & 800.4 & 12.2 & 171.7 & 1.2 & 1.0 & 1.9 & 13.2 & 0.1 & 0.7 & 136.0 & 0.6 & 0.1 & 7.2 & 11.7 \\
\hline C & 1014.4 & 10.4 & 1.8 & 1.2 & 0.0 & 0.2 & 0.2 & 0.0 & $<\mathrm{DL}$ & 0.4 & $<\mathrm{DL}$ & 0.5 & 7.4 & 0.0 \\
\hline
\end{tabular}

$<\mathrm{DL}$ : below detection limit. 
Table 8. Oxides obtained by XRF and carbon in nodules of profiles in the Lower Nhecolândia subregion of the Brazilian Pantanal, Mato Grosso do Sul

\begin{tabular}{|c|c|c|c|c|c|c|c|c|}
\hline Horizon & $\mathrm{SiO}_{2}$ & $\mathrm{Al}_{2} \mathrm{O}_{3}$ & $\mathrm{Fe}_{2} \mathrm{O}_{3}$ & $\mathrm{TiO}_{2}$ & $\mathrm{MnO}_{2}$ & $\mathbf{P}_{2} \mathbf{O}_{5}$ & C org & TC \\
\hline & & & & $-\mathrm{gk}$ & & & & \\
\hline P1 - Bhsc & 573.8 & 11.7 & 347.9 & 1.3 & 2.6 & 3.4 & 2.9 & 4.3 \\
\hline P1 - Bhc & 819.0 & 19.8 & 148.5 & 1.7 & 0.9 & 1.7 & 2.7 & 2.7 \\
\hline P2 - Bhsc & 763.5 & 17.6 & 184.3 & 1.8 & 5.0 & 0.9 & 2.0 & 4.1 \\
\hline P2 - Bhsc/E & 759.4 & 18.2 & 188.3 & 1.8 & 3.8 & 0.7 & 3.0 & 3.8 \\
\hline P2 - Bstc & 560.6 & 14.5 & 349.7 & 1.5 & 2.9 & 3.3 & 1.7 & 2.7 \\
\hline P2 - Bhc & 743.3 & 13.5 & 182.5 & 1.6 & 20.0 & 1.6 & 2.2 & 7.8 \\
\hline P3 - E1 & 851.5 & 13.3 & 40.6 & 1.6 & 73.5 & 0.3 & 0.0 & 3.7 \\
\hline P3 - E2 & 842.1 & 13.4 & 55.5 & 1.6 & 63.2 & 0.5 & 0.0 & 3.9 \\
\hline P4 - Bs1 & 343.7 & 11.2 & 521.3 & 1.1 & 1.2 & 4.2 & 1.5 & 2.9 \\
\hline P4 - Bs2 & 392.7 & 11.2 & 483.9 & 1.2 & 1.6 & 4.1 & 1.8 & 3.4 \\
\hline P4 - Bsc & 486.2 & 10.1 & 412.9 & 1.1 & 3.0 & 4.1 & 1.6 & 2.7 \\
\hline
\end{tabular}

C org: organic carbon; TC: total carbon.

from 148.5 to $521.3 \mathrm{~g} \mathrm{~kg}^{-1}$, from 0.9 to $20.0 \mathrm{~g} \mathrm{~kg}^{-1}$ and from 0.7 to $4.2 \mathrm{~g} \mathrm{~kg}^{-1}$, while in the eluvial horizons they varied from 40.6 to $55.5 \mathrm{~g} \mathrm{~kg}^{-1}$, from 63.2 to $73.5 \mathrm{~g} \mathrm{~kg}^{-1}$, and from 0.3 to $0.5 \mathrm{~g} \mathrm{~kg}^{-1}$. There was a greater accumulation of $\mathrm{Fe}_{2} \mathrm{O}_{3}$ and $\mathrm{P}_{2} \mathrm{O}_{5}$ in the $\mathrm{B}$ horizons of P4 than in the other profiles.

\section{Soil classification}

According to the SiBCS (Santos et al., 2018), spodic horizons are identified by the criteria: "color within the range of the different types of spodic horizons, have thickness greater than $2.5 \mathrm{~cm}$ ", accumulation of Fe and Al with low organic matter content. The SiBCS highlights that to quantify Fe and $\mathrm{Al}$, the elements should be extracted with oxalate solution $\left(\mathrm{Al}_{\circ}\right.$ and $\left.\mathrm{Fe}_{0}\right)$, but there is no criterion of a minimum value to define when there is "accumulation".

The $\mathrm{Al}_{0}$ contents in the profiles did not indicate $\mathrm{Al}$ accumulation in the $\mathrm{B}$ horizons (Table 7). Also, the difference between $\mathrm{Al}_{2} \mathrm{O}_{3}$ contents obtained by $\mathrm{XRF}$ and by sulfuric acid extraction only showed $\mathrm{Al}$ accumulation in the Bhc horizon of P2 and Btgn of P3 (Table 7). However, different distribution patterns were observed for Fe contents, when comparing total $\mathrm{Fe}_{2} \mathrm{O}_{3}$ with $\mathrm{Fe}_{\mathrm{d}}$ and $\mathrm{Fe}_{\mathrm{o}}$, which could indicate $\mathrm{Fe}$ accumulation in the $\mathrm{B}$ horizons of all profiles.

The definition of a spodic horizon in the SiBCS states the accumulation of organic matter, but the $\mathrm{C}$ org contents in the $\mathrm{B}$ horizons were lower. Also, as reported for $\mathrm{Al}_{0}$ and $\mathrm{Fe}_{0}$, the SiBCS does not define a minimum value of $\mathrm{C}$ org to evaluate organic matter accumulation. In this sense, the horizons met the definition of the Bs spodic horizon with "illuvial accumulation of amorphous material, mainly aluminum and iron combined with low contents of organic matter" (Santos et al., 2018). It is also relevant that the nodules have a higher carbon content than the fine earth, which could indicate a podzolization process. However, this possibility was not considered in the criteria that define spodic horizons.

Considering the sequence of horizons in the profiles and the current definitions in the SiBCS (Santos et al., 2018), without thresholds of $C$ org, Al and or Fe contents or $\mathrm{pH}$ values, all $\mathrm{B}$ horizons fit the criteria of $B$ espódicos. Thus, all profiles were classified as Espodossolos. Next, they were classified in the suborder of Humilúvicos - Bh underlying $\mathrm{A}$ (P2 and P3) and Ferri-humilúvicos - Bhs underlying A or E (P1 and P4). Since one or more horizons within $1.00 \mathrm{~m}$ were water-saturated and due to the presence of mottles in the spodic horizons, P1, P2 and P4 were classified in the great group of Hidromórficos, 
whereas P3 was classified as Órtico. Finally, P1, P2 and P4 were classified as típicos at the subgroup level, and P3 as arênico, due to the sandy texture from the surface to the upper limit of the B horizon (layer 0.85-1.05 m).

According to the international system IUSS Working Group WRB (2015), none of the B horizons met the criteria for spodic horizons, due to the $\mathrm{pH}\left(\mathrm{H}_{2} \mathrm{O}\right)$ above 5.9 and/or $\mathrm{C}$ org contents below $5.0 \mathrm{~g} \mathrm{~kg}^{-1}$. Thus, the profiles were classified, according to the horizons and attributes identified and the sequence of classes in the WRB key as: P1 - Sodic Arenosol; P2 - Sodic Stagnosol; P3 - Sodic Arenosol, and P4 - Sodic Arenosol.

\section{DISCUSSION}

\section{Pedoenvironment, soil profile morphology and particle-size distribution}

In the Lower Nhecolândia subregion, soils with spodic features occur in very specific areas and under restricted conditions, but not as registered by different publications and soil maps in extensive areas of the order of Espodossolos (Brasil, 1982; Fernandes et al., 2007; Santos et al., 2011). The soil map published by IBGE (2019b) already corrected the previous documents, since the Espodossolos are only presented in mapping units in association with other soil classes such as Neossolos Quartzarênicos (equivalent to Arenosols in the WRB).

The occurrence of these profiles in an area adjacent to the bay and in a transitional area between the bay and a "cordilheira" indicates the important role of high water levels at these landscape points for the formation of the spodic characteristics, acting as a physical barrier and preventing the descent of Fe and $\mathrm{C}$ org into deeper soil layers. In addition, the soil profiles showed that the landscape position has a strong influence on the horizon sequence and the topography of transitions between them, the solum depth, presence of mottles and nodule formation. The strongly restricted drainage in P1, P2 and P4 (bay area) prevents the formation and development of the E horizon. Similarly, the oscillation in the water table level promotes mottle formation and Fe and Mn nodules. In the transition between the bay and "cordilheira", the profile had a thick E horizon, less distinct mottles and a smaller amount of nodules. Soil profiles located at the highest and lowest elevation points of the transect (P3 and P4, respectively), have predominantly smooth and the others broken and wavy horizon transitions (P1 and P2).

Along the transect, the E horizon formation begins at P2 and advances laterally to P3. In this landscape section, the stability of the water table at the top of $\mathrm{C}$ horizon, during most of the year, is indicated by the smooth topography between the $B$ and $C$ horizons and the less frequent occurrence or absence of mottles in the profile.

In hydrosequences of Podzols (Espodossolos) in the coastal area of southeastern Brazil, Buurman et al. (2013) and Lopes-Mazzetto et al. (2018) also correlated the presence of mottles, topography of the horizon transitions and development of the $\mathrm{E}$ horizon with the water flow in the profiles. In these two studies, imperfectly drained profiles had predominantly wavy or broken transitions between the spodic and overlying horizons, whereas more poorly drained soils had predominantly smooth transitions. According to Lopes-Mazzetto et al. (2018), mottles occur in the B horizon in imperfectly drained soils due to Fe oxide precipitation, while poorly drained soils had no mottles and low Fe contents. According to Buurman et al. (2013), the conversion of a spodic into an E horizon begins with the appearance of areas of organic matter depletion due to intense biological activity, so that the thickening of the E horizon is directly associated with the variation in the water table.

Iron and Mn nodules in the studied profiles were not derived from past conditions or inherited from the sedimentary parent material. This statement assumes that due to water stagnation during the wet season in the Pantanal, elements such as $\mathrm{Fe}^{3+}, \mathrm{Mn}^{3+}$ 
and $\mathrm{Mn}^{4+}$ in pre-existing nodules would change to the reduced form and migrate in the soil solution, according to the redox potential and flood period. Thus, nodule formation in the water table fluctuation zone, which occurs in the B horizons of bay soils and $E$ horizons of $\mathrm{P} 3$, is related to the intermittence of the current seasonal flooding conditions and results from a redoximorphic process (Vepraskas, 2015).

Under prolonged water saturation, when $\mathrm{O}_{2}$ availability for biological respiration is reduced, other ions are used as final electron acceptors. Thus, as the redox potential is reduced, the $\mathrm{Fe}^{3+}, \mathrm{Mn}^{3+}$ and $\mathrm{Mn}^{4+}, \mathrm{NO}^{3-}$, sulfides, sulfates, organic matter dissimilation products and $\mathrm{H}^{+}$present in the soil solution are consumed in anaerobic respiration (Bartlett and James, 1993). In the reduced form, the $\mathrm{Fe}^{2+}$ and $\mathrm{Mn}^{2+}$ ions migrate in the soil solution according to the redox gradient and precipitate in oxidized soil zones, such as inside aggregates, pores, roots, or in oxidized zones generated as the water table sinks. When the water table level oscillates seasonally, the Fe movement occurs in fluxes, which can lead to the formation of a placic horizon (Kämpf and Curi, 2012).

The presence of nodules in the subsurface horizons was previously found during a field trip of the 10th Brazilian Soil Classification and Correlation Meeting (RCC, 2012). The preservation of Fe originated from sediments of the Pantanal Formation with ferruginous features (Godoi et al., 2001) is favored by the substantially flat relief, in which the leaching or lateral removal of this element is almost non-existent (Assine, 2005).

Soils in the Pantanal basin are shallow and their genesis is strongly influenced by the restricted drainage, in the rainy season, and the nature of the sediments. In addition, the dry season and influence of the lakes lead to peculiar pedogenetic processes (Furquim et al., 2010, 2017; Andrade et al., 2020), especially when compared to the soils classified as Espodossolos in other environments of Brazil (Menezes et al., 2018) and the Podzols described in the literature (Beyer, 1996; Buurman et al., 2013; Ferro-Vázquez et al., 2014; Valerio et al., 2016; Ishida et al., 2018; Silva Neto et al., 2018; Lopes-Mazzetto et al., 2018; Tadini et al., 2018; Rêgo et al., 2019; Schiavo et al., 2020; Brock et al., 2020).

In general, the soils with spodic features in Lower Nhecolândia have weak or subtle morphological characteristics and profile development, and a higher content of nodules. In comparison, the Espodossolos under hydromorphic conditions described in the coastal region and Amazonia plains have clearly defined morphological characteristics of the spodic horizons, whereas the presence of nodules is not common (Buurman et al., 2013; Lopes-Mazzetto et al., 2018; Silva Neto et al., 2018; Tadini et al., 2018; Schiavo et al., 2020).

The sandy texture of the soils in this study is a common feature of Espodossolos of different Brazilian environments (Schaefer et al., 2002; Simas et al., 2005; Buurman et al. 2013; Ishida et al, 2018; Lopes-Mazzetto et al., 2018; Silva Neto et al., 2018; Tadini et al., 2018; Rêgo et al., 2019; Schiavo et al., 2020). The same is true for Podzols in temperate or boreal climate regions (Beyer, 1996; Ferro-Vázquez et al., 2014; Valerio et al., 2016; Brock et al., 2020). The predominance of the fine sand fraction reflects the particle size of the parent material and was previously observed in the Pantanal in the same landscape during the RCC (2012) and Schiavo et al. (2012).

Although the Pantanal is a large sedimentary basin, the soils show no signs of deposition of different sediments, such as variation in particle size fractions along the profiles. To corroborate this, the profile MS-1 characterized by RCC (2012), located at the same site as profile $\mathrm{P} 3$ of this study, had no mineralogical properties that would indicate any difference between the parent material of $\mathrm{E}$ and Btgn horizons. The micromorphology of the Btgn horizon of profile MS-1 also indicated illuvial clay coatings and fillings, as well as Fe coating in the pores (RCC, 2012), as evidence of translocation of these materials within the profile. 
Thus, clay accumulation in the B horizons of the studied soils can be assumed to be due to the illuviation process. This is not restricted to the Pantanal soils, but is true for other sedimentary landscapes of Brazil, e.g., in the coastal plains (Silva Neto et al., 2018) and coastal tablelands (Rêgo et al., 2019; Schiavo et al., 2020). It was also observed in Podzols in France (Guillet et al., 1975) and sub-alpine forests in Taiwan (Liu and Chen, 2004).

\section{Chemical attributes, pedogenetic oxides and elemental composition}

In general, spodic horizons in Brazilian pedoenvironments have $\mathrm{pH}\left(\mathrm{H}_{2} \mathrm{O}\right)$ around 5.0, $\mathrm{S}$ values below $1.0 \mathrm{cmol}_{\mathrm{c}} \mathrm{kg}^{-1}, \mathrm{C}$ org above $5.0 \mathrm{~g} \mathrm{~kg}^{-1}$ and $\mathrm{Al}_{\mathrm{o}}$ above $1.0 \mathrm{~g} \mathrm{~kg}^{-1}$, according to the analysis of 385 spodic horizons by Menezes et al. (2018). Therefore, the chemical attributes of the horizons with spodic features highlight the uniqueness of the Pantanal environment, in which the soils differ in $\mathrm{S}$ values $\left(>1.0 \mathrm{cmol}_{c} \mathrm{~kg}^{-1}\right), \mathrm{pH}\left(\mathrm{H}_{2} \mathrm{O}\right)$ (predominantly $\geq 6.0$ ), low contents of $\mathrm{C}$ org and $\mathrm{Al}_{0}$, and high exchangeable bases, with occurrence of solodic and sodic characters.

The local bays in Lower Nhecolândia, according to Barbiéro et al. (2002), contain sodic/calcic/ sometimes potassic and carbonated/chlorinated water. In addition, the water table stagnation in the profiles adjacent to the bay (P1, P2 and P4) and the presence of a less permeable horizon, in the transition area between the bay and "cordilheira" (P3), reduce the leaching of exchangeable cations. According to Fernandes et al. (1999), a greenish horizon with low permeability, indicating strong reduction conditions, often occurs at a distance of 1 to $4 \mathrm{~m}$ from "cordilheiras".

The said characteristics are antagonistic to the three main theories of the podzolization process: the complexation theory, the proto-imogolite theory and the metal reduction theory, which require acidolysis conditions for the Fe and Al release from primary or clay minerals, as well as low levels of cations that would promote organic matter dispersion (De Coninck, 1980; Farmer et al., 1980; Chesworth and Macias-Vasquez, 1985; Lundström et al., 2000; Sauer et al., 2007). Additionally, according to the complexation and metal-reduction theories, the action of organic matter is necessary, making the two theories contradictory in the Pantanal environment where very low levels of $C$ org are observed. On the other hand, the absence or very low levels of $\mathrm{Al}_{0}$ in the $\mathrm{B}$ horizons are not compatible with the proto-imogolite theory.

According to the complexation theory, from the humified organic matter on the soil surface complex, Fe and Al oxides are formed in the surface horizon. By water percolation and due to the high soil permeability, these chelates are transported to the subsurface, precipitated by different immobilization mechanisms, which leads to the formation of a spodic horizon (De Coninck, 1980; Lundström et al., 2000; Sauer et al., 2007). In the metal-reduction theory, the Fe present in the oxides is reduced by the presence of reducing organic substances released from the litter of different species, then forming ferric-organic complexes that can be translocated and result in the formation of the spodic horizon (Sauer et al., 2007). The proto-imogolite theory states that the mobilization of polyvalent cations is associated to the formation of hydroxy-Al-Si-Fe mobile orthosilicates (proto-imogolite), with positive charges, caused by weathering of the $A$ and $E$ horizons (Farmer et al., 1980). With the water action, these silicates are transported and precipitated in the B horizon as Fe or Al oxides, or in the form of imogolite-like materials. In a later step, organic acids would be mobilized and their accumulation in the B horizon would be due to the adsorption of negatively charged organic acids in the inorganic fraction.

That said, comparing the Podzols developed in temperate climates, where spodic horizons commonly have higher $\mathrm{C}$ org contents as well as $\mathrm{pH}\left(\mathrm{H}_{2} \mathrm{O}\right)$ below 5.0, the profiles in Lower Nhecolândia seem even more peculiar. In a lowland environment in northwest Germany, spodic horizons evaluated by Beyer (1996) had C org contents predominantly above $10 \mathrm{~g} \mathrm{~kg}^{-1}$, reaching up to $80 \mathrm{~g} \mathrm{~kg}^{-1}$. In Netherland, Brock et al. (2020) reported C org contents of spodic horizons, mostly above $10 \mathrm{~g} \mathrm{~kg}^{-1}$ and up to $78.1 \mathrm{~g} \mathrm{~kg}^{-1}$, while $\mathrm{pH}\left(\mathrm{H}_{2} \mathrm{O}\right)$ values were 
below 4.0. On the Galician coast, spodic horizons studied by Ferro-Vasquez et al. (2014) had $\mathrm{pH}\left(\mathrm{H}_{2} \mathrm{O}\right)$ below 5.0 and $\mathrm{C}$ org between 17.8 and $38.6 \mathrm{~g} \mathrm{~kg}^{-1}$.

Regarding the podzolization process in the soil profiles studied in the Pantanal by many authors, there are no conclusive remarks. For spodic horizons in Lower Nhecolândia, the only reference in literature with micromorphological data, a relevant analysis to identify the podzolization process, describes the Bsm/En horizon and the transition between the Bs/En and Bmn horizons of the MS-5 profile, described by the 10th Brazilian Soil Classification and Correlation Meeting (RCC, 2012). In those horizons, an abundant part of the porous space was completely filled with dense ferruginous, clay and iron fillings while there was no organic matter filling pores or covering aggregates.

In Lower Nhecolândia, evapotranspiration outweighs precipitation, which favors salt accumulation (Soriano, 2000). Also, the water table level in the areas adjacent to the bays, whose water has a sodic, calcic and eventually potassic nature, acts as $\mathrm{Na}^{+}$and $\mathrm{K}^{+}$supplier in the subsurface and maintains these elements in the system, since it is a physical barrier to leaching, which justifies the occurrence of sodic and solodic horizons in the Pantanal. Especially in the transitional area of bay and "cordilheira", $\mathrm{Na}^{+}$and $\mathrm{K}^{+}$ leaching is also hampered by the low permeability of the horizon.

Thus, the soils under study show conditions for the process of sodification, characterized by the influence of $\mathrm{Na}^{+}$on the dispersion of silicate clays and organic matter, which, due to the high permeability of the parent material and water inflow, are then transported vertically (Miller and Brierley, 2011). However, the drainage impediment, due to the seasonally high water level, leads to clay and organic matter accumulation, even in small quantities, in the B horizons of all profiles. In this sense, the characteristics of the studied profiles, with spodic features and sodic and solodic characters, as well as the clay and salt accumulation in the Btgn horizon of P3, confirmed the occurrence of this pedogenetic process in Lower Nhecolândia. Compared to other soils with spodic horizons, the ESP values, usually greater than or equal to $6 \%$, are uncommon; in other Brazilian environments; in general, they are equal to or close to zero (Schaefer et al., 2002; Simas et al., 2005; Rêgo et al., 2019; Schiavo et al., 2020).

Iron contents, in total $\left(\mathrm{Fe}_{2} \mathrm{O}_{3}\right)$, free $\left(\mathrm{Fe}_{\mathrm{d}}\right)$ and amorphous $\left(\mathrm{Fe}_{0}\right)$ forms in the horizons with spodic features indicate the accumulation of this element in subsurface. Subtracting the $\mathrm{Fe}_{2} \mathrm{O}_{3}$ contents obtained by XRF and sulfuric acid extraction showed accumulation not only in the clay fraction, but possibly associated with organic matter and/or the sand fraction of $\mathrm{P} 2, \mathrm{P} 3$ and $\mathrm{P} 4$. Although the $\mathrm{Al}_{0}$ contents did not indicate accumulation of this element in the $\mathrm{B}$ horizons, total aluminum $\left(\mathrm{Al}_{2} \mathrm{O}_{3}\right)$ and the subtraction of the $\mathrm{Al}_{2} \mathrm{O}_{3}$ contents obtained by XRF and sulfuric acid extraction denoted an accumulation of this element in the horizons with spodic features, which could be related to clay illuviation, association with organic matter and/or presence of these oxides in the sand fraction.

The possibility of Fe and Al oxides originating from the sand fraction is due to the presence of fragments of nodules in these horizons. In addition, these oxides may have been associated with dissolved organic matter, present in greater amounts in soils with stagnant water and which can combine with oxides already existing in the subsurface (Rennert et al., 2014).

The $\mathrm{Fe}_{\mathrm{o}}$ and $\mathrm{Fe}_{\mathrm{d}}$ contents of the $\mathrm{B}$ horizons in the soils studied were high in comparison to spodic horizons in other Brazilian sedimentary environments, with frequently less than $1.0 \mathrm{~g} \mathrm{~kg}^{-1}$ (Menezes et al., 2018). However, the $\mathrm{Fe}_{o}$ and $\mathrm{Fe}_{\mathrm{d}}$ levels were close to those observed in soils of high altitude mountains of Brazil and the spodic horizons formed in temperate climate, where leaching losses are less intense (Beyer, 1996; Schaefer et al., 2002; Simas et al., 2005). On the other hand, the $\mathrm{Al}_{\mathrm{o}}$ contents of the $\mathrm{B}$ horizons were very low in comparison with the spodic horizons of other Brazilian pedoenvironments, which normally have $\mathrm{Al}_{0}$ accumulation and values above $1.5 \mathrm{~g} \mathrm{~kg}^{-1}$ (Menezes et al., 2018). 
For spodic horizons of hydromorphic Espodossolos of the coastal plain, Gomes et al. (2007) and Coelho et al. (2010) reported a $\mathrm{Fe}_{o} / \mathrm{Fe}_{d}$ ratio close to 1.0. The spodic horizons described by Schiavo et al. (2012) and at the 10th Brazilian Soil Classification and Correlation Meeting (RCC, 2012) had predominantly lower than or equal to $0.5 \mathrm{Fe}_{0} / \mathrm{Fe}_{\mathrm{d}}$ ratios, similarly to the $B$ horizons of this study.

The variations in $\mathrm{Mn}$ in total $\left(\mathrm{MnO}_{2}\right)$, free $\left(\mathrm{Mn}_{\mathrm{d}}\right)$ and amorphous $\left(\mathrm{Mn}_{0}\right)$ forms evidence the accumulation of this element, mainly in horizons with nodules and in the Btgn horizon, which had a grayish-green and black variegated color. Thus, considering that Btgn has a very low $\mathrm{C}$ org content, the black color of this horizon was attributed to $\mathrm{Mn}$ accumulation.

Manganese occurs in soils in different minerals, generally with a low degree of crystallinity and in low amounts (Carvalho Filho et al., 2011). Therefore, Mn oxide extraction by sodium dithionite-citrate-bicarbonate and ammonium acid oxalate is not a routine analysis. The $M n_{d}$ and $M n_{0}$ contents are very close, which corroborates the prevalence of less crystalline forms of these oxides in the studied soils. Although the extraction by sodium dithionite-citrate-bicarbonate identifies both the more and the less crystalline forms, the $M n_{0}$ contents exceeded the $\mathrm{Mn}_{\mathrm{d}}$ contents in the soils under study, which indicates that part of the $\mathrm{Mn}$ in the oxides was not reduced in the analyses. In the MS-1 profile of the 10th Brazilian Soil Classification and Correlation Meeting (RCC, 2012), $M n_{0}$ also exceeded $M n_{d}$.

The variations in Ti oxides $\left(\mathrm{TiO}_{2}\right)$ did not indicate lithological discontinuity in the studied soils and the distribution in depth was related to the clay content, which was evident in the $\mathrm{Btgn}$ horizon of $\mathrm{P} 3$, which had the highest $\mathrm{TiO}_{2}$ and clay contents. The $\mathrm{SiO}_{2}$ contents corroborated the siliceous nature of the parent material (Godoi et al., 2001), and the higher $\mathrm{P}_{2} \mathrm{O}_{5}$ levels in the horizons with nodules suggested the contribution of its fragments to $\mathrm{P}$ contents.

\section{Carbon and elemental composition of nodules}

Soil nodules usually have low carbon contents in their composition and, unlike concretions, no internal organization (Santos et al., 2015). On the occasion of the 10th Brazilian Soil Classification and Correlation Meeting (RCC, 2012), ferruginous nodules were identified in the micromorphology of horizons of the MS-1 profile, but the chemical composition or presence of organic material in these nodules was not evaluated. The nodules with a higher carbon content than the soil matrix point to the formation of a spodic horizon, although the other chemical attributes diverge from pedogenesis by the podzolization process.

Nodules with higher organic matter, iron and manganese contents than the surrounding material were also observed by Rennert et al. (2014) in a soil classified as Stagnosol in East Germany. The authors observed a preferential association of organic matter with iron rather than $\mathrm{Mn}$ and concluded that progressive redox cycles and possible clay illuviation reduced the pore space within nodules and concretions, causing restricted accessibility for microorganisms. Thus, microbial degradation was inhibited and consequently, organic matter was stabilized in the Fe and Mn nodules and concretions.

The Al content of nodules compared to that of fine earth and the increase in organic carbon in nodules in relation to the soil matrix indicated that Al illuviation by podzolization is rather unlikely. These facts also reinforce the possibility that the difference between the $\mathrm{Al}_{2} \mathrm{O}_{3}$ contents obtained by XRF and sulfuric acid extraction was due to the presence of nodule fragments in the sand fraction. The greater amount of $\mathrm{Fe}_{2} \mathrm{O}_{3}$ in the $\mathrm{B}$ horizons of $\mathrm{P} 4$ might be related to the profile position in the landscape, since this profile had the lowest elevation, resulting in greater $\mathrm{Fe}^{2+}$ accumulation in the flooding period in relation to other profiles of the transect. 


\section{Soil classification}

Considering the principles and structure of the SiBCS (Santos et al., 2018), the identification of diagnostic horizons is mainly based on morphopedogenetic characteristics. In this sense, the classification of profiles in the Lower Nhecolândia region, selected in this study for their spodic features, reinforces the possibility of discrepancies in the taxonomy of soils with spodic features and their pedogenesis, according to concepts adopted by international systems and usually cited in the literature. This observation emphasizes the need for quantitative criteria and thresholds for attributes such as $\mathrm{C}$ org, Al and Fe as well as for quantification methods, so that the podzolization process can be properly defined by the SiBCS and identified in Brazilian soils.

The classification of the spodic horizon, according to the current criteria of the SiBCS (Santos et al., 2018), is contradictory to the international systems, due to the lack of threshold values to identify the occurrence of illuviation of organic matter, Al and Fe as well as methods to be used to evaluate the accumulation of pedogenetic oxides in this horizon. When evaluating the $\mathrm{Al}_{\mathrm{o}}$ contents of the studied profiles by the recommended method, it could be interpreted that these horizons are not spodic, since Al accumulation is a condition established by the SiBCS to define this diagnostic horizon. Thus, in this study the identification of the horizons as spodic was based on their morphology and on Al analysis by XRF, which is not a routine method.

To improve the definition of the spodic horizon of the SiBCS, an adjustment of the requirement for $\mathrm{Al}$ accumulation is proposed, similarly to that for the placic horizon: "presenting apparent cementation of iron (or iron and manganese) and organic matter", i.e., not necessarily with $\mathrm{Al}$ in the composition. As a further support of this proposal, the metal-reduction theory focused on the podzolization process does not explain Al illuviation, but the Fe mobilization (Sauer et al., 2007). In addition, the international system WRB (IUSS WORKING GROUP WRB, 2015) allows for the identification of spodic horizons based on the accumulation of illuvial Fe only.

The soils in Lower Nhecolândia have characteristics that are not associated with spodic horizons and classification of Espodossolos in the SiBCS or with the podzolization process, such as a sufficiently high Na contents to define sodic and solodic characters. Thus, these characters should be included in the SiBCS at least in the subgroup level of Espodossolos. It should be mentioned that although SiBCS defines that sandy-textured soils cannot be considered eutrophic when base saturation is above or equal to $50 \%$, there is no restriction against attributing the sodic or solodic character to sandy-textured soils (Santos et al., 2018).

\section{CONCLUSIONS}

Hydrological conditions with high water level in the bay area (P1, P2 and P4) regulate a redoximorphic process, as observed by the variegated and reducing colors, mottles, absence of an E horizon, presence of nodules and Fe and Mn oxides, as well as a shallow soil profile.

Chemical attributes, neutral to alkaline $\mathrm{pH}$, high sum of bases, low $\mathrm{C}$ org and low $\mathrm{Al}$ in the $\mathrm{B}$ horizon contradict the classical podzolization pedogenesis. On the other hand, $\mathrm{Fe}, \mathrm{Al}$ and $\mathrm{C}$ org accumulation in the nodules found in $\mathrm{B}$ horizons reinforces the morphology of spodic horizons.

Accumulation of Fe and $\mathrm{C}$ org in $\mathrm{B}$ horizons is also related to the sodification and redoximorphic processes, as well as higher carbon, Fe, and $\mathrm{Mn}$ contents in the nodules, without a relative increase in $\mathrm{Al}$, compared to the soil matrix. 
The complexity of features and characteristics of the soil profiles of Lower Nhecolândia indicates that multiple pedogenetic processes occur in this environment. Thus, more studies on the micromorphology and variations in the landscape are required, and minimum values should be established for attributes considered diagnostic for spodic horizons in the SiBCS, e.g., pH, C org, Al and Fe. In this way, the taxonomy of these soils would be adjusted according to their pedogenesis.

\section{ACKNOWLEDGMENT}

The authors are indebted to the staff of the experimental Fazenda Nhumirim and Embrapa Pantanal for allowing the field collection, Embrapa Solos for analyzing the soils, and the Brazilian Council for Scientific and Technological Development (CNPq) and Brazilian Federal Agency for Support and Evaluation of Graduate Education (CAPES) for financial support.

\section{REFERENCES}

Andrade GRP, Furquim SAC, Nascimento TTV, Brito AC, Camargo GR, Souza G. Transformation of clay minerals in salt-affected soils, Pantanal wetland, Brazil. Geoderma. 2020;371:114380. https://doi.org/10.1016/j.geoderma.2020.114380

Aparecido LEO, Moraes JRSC, Meneses KC, Torsoni GB, Lima RF, Costa CTS. Köppen-Geiger and Camargo climate classifications for the Midwest of Brasil. Theor Appl Climatol. 2020;142:1133-45. https://doi.org/10.1007/s00704-020-03358-2

Assine ML. River avulsions on the Taquari megafan, Pantanal wetland, Brazil. Geomorphology. 2005;70:357-71. https://doi.org/10.1016/j.geomorph.2005.02.013

Barbiéro L, Queiroz Neto JP, Ciornei G, Sakamoto AY, Capellari B, Fernandes E, Valles V. Geochemistry of water and ground water in the Nhecolândia, Pantanal of Mato Grosso, Brazil: variability and associated processes. Wetlands. 2002;22:528-40. https://doi.org/10.1672/0277-5212(2002)022[0528:GOWAGW]2.0.CO;2

Bartlett RJ, James BR. Redox chemistry of soil. Adv Agron. 1993;50:151-208. https://doi.org/10.1016/S0065-2113(08)60834-2

Beyer L. Soil organic matter composition of spodic horizons in Podzols of the Northwest German Lower Plain. Sci Total Environ. 1996;181:167-80. https://doi.org/10.1016/0048-9697(95)05007-8

Boin MN, Martins PCS, Silva CA, Salgado AAR. Pantanal: The Brazilian Wetlands. In: Salgado AAR, Santos LJC, Paisani JC, editors. The physical geography of Brazil: Environment, vegetation and landscape. Cham: Springer; 2019. p. 75-91.

Brasil. Departamento Nacional de Produção Mineral. Projeto Radambrasil. Folha SE. 21 Corumbá e parte da folha SE.20: geologia, geomorfologia, pedologia, vegetação, uso potencial da terra. Rio de Janeiro; 1982. (Levantamento de Recursos Naturais, v. 27).

Brock O, Kalbitz K, Absalah S, Jansen B. Effects of development stage on organic matter transformation in Podzols. Geoderma. 2020;378:114625. https://doi.org/10.1016/j.geoderma.2020.114625

Buurman P, Vidal-Torrado P, Martins VM. The Podzol hydrosequence of Itaguaré (São Paulo, Brazil). 1. Geomorphology and interpretation of profile morphology. Soil Sci Soc Am J. 2013;77:1294-306. https://doi.org/10.2136/sssaj2012.0080

Carvalho Filho A, Curi N, Marques JJGSM, Shinzato E, Freitas DAF, Jesus EA, Massahud RTR. Óxidos de manganês em solos do Quadrilátero Ferrífero (MG). Rev Bras Cienc Solo. 2011;35:793-804. https://doi.org/10.1590/s0100-06832011000300015

Chesworth W, Macias-Vasquez F. Pe, pH, and podzolization. Am J Sci. 1985;285:128-46. https://doi.org/10.2475/ajs.285.2.128

Coelho MR, Vidal-Torrado P, Perez XLO, Martins VM, Vázquez FM. Fracionamento do alumínio por técnicas de dissoluções seletivas em Espodossolos da planície costeira do Estado de São Paulo. Rev Bras Cienc Solo. 2010;34:1081-92. https://doi.org/10.1590/s0100-06832010000400008 
De Coninck F. Major mechanisms in formation of spodic horizons. Geoderma. 1980;24:101-28. https://doi.org/10.1016/0016-7061(80)90038-5

Farmer VC, Russell JD, Berrow ML. Imogolite and proto-imogolite allophane in spodic horizons: evidence for a mobile aluminium silicate complex in Podzol formation. J Soil Sci. 1980;31:673-84. https://doi.org/10.1111/j.1365-2389.1980.tb02113.x

Fernandes E, Sakamoto AY, Queiroz Neto JP, Lucati HM, Capellari B. Le Pantanal da Nhecolândia Mato Grosso: Cadre physique et dynamique hydrologique. Suppl Geogr Fis Dinam Quat. 1999;22:13-21.

Fernandes FA, Fernandes AHBM, Soares MTS, Pellegrin LA, Lima IBT. Atualização do mapa de solos da planície pantaneira para o Sistema Brasileiro de Classificação de Solos. Corumbá: Embrapa Pantanal; 2007. (Comunicado técnico, 61). Available from: https://ainfo.cnptia.embrapa.br/digital/bitstream/item/161349/1/COT61.pdf.

Ferro-Vázquez C, Nóvoa-Muñoz JC, Costa-Casais M, Klaminder J, Martínez-Cortizas A. Metal and organic matter immobilization in temperate podzols: A high resolution study. Geoderma. 2014;217-218:225-34. https://doi.org/10.1016/j.geoderma.2013.10.006

Furquim SAC, Graham RC, Barbiero L, Queiroz Neto JP, Vidal-Torrado P. Soil mineral genesis and distribution in a saline lake landscape of the Pantanal Wetland, Brazil. Geoderma. 2010;154:3-4. https://doi.org/10.1016/j.geoderma.2009.03.014

Furquim SAC, Santos MA, Vidoca TT, Balbino MA, Cardoso EL. Salt-affected soils evolution and fluvial dynamics in the Pantanal wetland, Brazil. Geoderma. 2017;286:139-52. https://doi.org/10.1016/j.geoderma.2016.10.030

Godoi HO, Martins EG, Mello JCR, Scislewski G. Programa levantamentos geológicos básicos do Brasil - PLGB. Corumbá - Folha SE.21-Y-D, Aldeia Tomázia - Folha SF.21-V-B, Porto Murtinho - Folha SF.21-V-D, Estado de Mato Grosso do Sul. Escala 1:250.000. Brasília, DF: CPRM/DIEDIG/ DEPAT; 2001. Available from: https://rigeo.cprm.gov.br/bitstream/doc/5658/1/Rel_Corumba.pdf.

Gomes FH, Vidal-Torrado P, Macías F, Gherardi B, Perez XLO. Solos sob vegetação de restinga na Ilha do Cardoso (SP): I - Caracterização e classificação. Rev Bras Cienc Solo. 2007;31:1563-80. https://doi.org/10.1590/s0100-06832007000600033

Guillet B, Rouiller J, Souchier B. Podzolization and clay migration in Spodosols of eastern France. Geoderma. 1975;14:223-45. https://doi.org/10.1016/0016-7061(75)90003-8

Hamilton SK, Souza OC, Coutinho ME. Dynamics of floodplain inundation in the alluvial fan of the Taquari River (Pantanal, Brazil). Int Ver The. 1998;26:916-22. https://doi.org/10.1080/03680770.1995.11900852

Instituto Brasileiro de Geografia e Estatística - IBGE. Biomas e sistema costeiro-marinho do Brasil: Compatível com a escala 1:250.000. Rio de Janeiro: IBGE, Coordenação de Recursos Naturais e Estudos Ambientais; 2019a. (Série relatórios metodológicos). Available from: https://biblioteca.ibge.gov.br/visualizacao/livros/liv101676.pdf.

Instituto Brasileiro de Geografia e Estatística - IBGE. Províncias estruturais, compartimentos de relevo, tipos de solos, regiões fitoecológicas e outras áreas. Rio de Janeiro: IBGE; 2019b. Available from: https://biblioteca.ibge.gov.br/visualizacao/livros/liv101648.pdf

Instituto Brasileiro de Geografia e Estatística - IBGE. Base cartográfica contínua do Brasil na escala 1:250000. Rio de Janeiro: IBGE; 2019c [cited 2021 Mar 29]. Available from: https://geoftp.ibge.gov.br/cartas_e_mapas/bases_cartograficas_continuas/bc250/versao2019/.

Ishida DA, Vieira-Coelho AC, Melfi AJ, Lucas Y, Camargo JPB, Montes CR. Influence of pedogenetic processes on the validity of kaolinite crystallinity indices: a case study of an Amazonian Ferralsol-Podzol soil system with white kaolin. Appl Clay Sci. 2018;162:435-42. https://doi.org/10.1016/j.clay.2018.06.025

IUSS Working Group WRB. World reference base for soil resources 2014, update 2015 : International soil classification system for naming soils and creating legends for soil maps. Rome: Food and Agriculture Organization of the United Nations; 2015. (World Soil Resources Reports, 106).

Jahn R, Blume HP, Asio VB, Spaargaren O, Schad P. Guidelines for soil description. 4th ed. Rome: FAO; 2006. 
Kämpf N, Curi N. Formação e evolução do solo (pedogênese). In: Ker JC, Curi N, Schaefer CEGR, Vidal-Torrado P, editors. Pedologia: Fundamentos. Viçosa, MG: Sociedade Brasileira de Ciência do Solo; 2012. p. 207-302.

Liu JC, Chen ZS. Soil characteristics and clay mineralogy of two subalpine forest Spodosols with clay accumulation in Taiwan. Soil Sci. 2004;169:66-80. https://doi.org/10.1097/01.ss.0000112013.97541.74

Lopes-Mazzetto JM, Buurman P, Schellekens J, Martinez PHRM, Vidal-Torrado P. Soil morphology related to hydrology and degradation in tropical coastal podzols (SE Brazil). Catena. 2018;162:1-13. https://doi.org/10.1016/j.catena.2017.11.007

Lundström US, Van Breemen N, Bain D. The podzolization process. A review. Geoderma 2000;94:91-107. https://doi.org/10.1016/s0016-7061(99)00036-1

Menezes AR, Fontana A, Anjos LHC. Spodosols in Brazil: Distribution, characteristics and diagnostic properties of spodic horizons. South Afr J Plant Soil. 2018;35:241-50. https://doi.org/10.1080/02571862.2017.1410734

Miller JJ, Brierley JA. Solonetzic soils of Canada: Genesis, distribution, and classification. Can J Soil Sci. 2011;91:889-902. https://doi.org/10.4141/cjss10040

Rêgo LGS, Silva JJA, Souza CMM, Portela JC, Moura INBM, Silva ACR, Miranda NO. Pedogenesis in the Barreiras formation under climates of Rio Grande do Norte, Brazil. J Agric Sci. 2019;11:19-29. https://doi.org/10.5539/jas.v11n16p19

Rennert T, Händel M, Höschen C, Lugmeier J, Steffens M, Totsche K. A NanoSIMS study on the distribution of soil organic matter, iron and manganese in a nodule from a Stagnosol. Eur J Soil Sci. 2014;65:684-92. https://doi.org/10.1111/ejss.12157

Reunião Brasileira de Classificação e Correlação de Solos - RCC. Guia de excursão de estudos de solos no Pantanal e Cerrados do Estado do Mato Grosso do Sul. Corumbá: Embrapa Pantanal; Rio de Janeiro: Embrapa Solos; 2012.

Santos HG, Carvalho Júnior W, Áglio MLD, Silva JS, Dart RO, Pares JG, Fontana A, Martins ALS, Oliveira AP. Mapa de Solos do Brasil. Rio de Janeiro: Embrapa Solos; 2011.

Santos HG, Jacomine PKT, Anjos LHC, Oliveira VA, Lumbreras JF, Coelho MR, Almeida JA, Araújo Filho JC, Oliveira JB, Cunha TJF. Sistema brasileiro de classificação de solos. 5. ed. rev. ampl. Brasília, DF: Embrapa; 2018.

Santos RD, Lemos RC, Santos HG, Ker JC, Anjos LHC, Shimizu SH. Manual de descrição e coleta de solo no campo. 7. ed. rev. e ampl. Viçosa, MG: Sociedade Brasileira de Ciência do Solo; 2015.

Sauer D, Sponagel H, Sommer M, Giani L, Jahn R, Stahr K. Soil of the year 2007: A review on its genesis, occurrence, and functions. J Plant Nutr Soil Sci. 2007;170:581-97. https://doi.org/10.1002/jpln.200700135

Schaefer CER, Ker JC, Gilkes RJ, Campos JC, Costa LM, Saadi A. Pedogenesis on the uplands of the Diamantina Plateau, Minas Gerais, Brazil: A chemical and micropedological study. Geoderma. 2002;107:243-69. https://doi.org/10.1016/s0016-7061(01)00151-3

Schiavo JA, Dias Neto AH, Pereira MG, Rosset JS, Secretti M, Pessenda LCR. Characterization and classification of soils in the Taquari river basin - Pantanal region, state of Mato Grosso do Sul, Brazil. Rev Bras Cienc Solo. 2012;36:697-708. https://doi.org/10.1590/s0100-06832012000300002

Schiavo JA, Pessenda LCR, Buso Júnior AA, Calegari MR, Fornari M, Secretti ML, Pereira MG, Mayle FE. Genesis and variation spatial of Podzol in depressions of the Barreiras Formation, northeastern Espírito Santo State, Brazil, and its implications for Quaternary climate change. J South Am Earth Sci. 2020;98:102435. https://doi.org/10.1016/j.jsames.2019.102435

Silva Neto EC, Calegari MR, Pereira MG, Maranhão DDC, Schiavo JA, Fontana A, Fernandes JCF. Phytoliths as indicators of pedogenesis and paleoenvironmental changes in Spodosols of the state of Rio de Janeiro, Brazil. Sci Total Environ. 2018;636:1070-80. https://doi.org/10.1016/j.scitotenv.2018.04.313 
Simas FNB, Schaefer CEGR, Fernandes Filho El, Chagas AC, Brandão PC. Chemistry, mineralogy and micropedology of highland soils on crystalline rocks of Serra da Mantiqueira, southeastern Brazil. Geoderma. 2005;125:187-201. https://doi.org/10.1016/j.geoderma.2004.07.013

Soriano BMA. Boletim agrometeorológico: 1997 (Fazenda Nhumirim). Corumbá: Embrapa Pantanal; 2000. (Boletim agrometeorológico, 4)

Tadini AM, Nicolodelli G, Senesi GS, Ishida DA, Montes CR, Lucas Y, Mounier S, Guimarães FEG, Milori DMBP. Soil organic matter in Podzol horizons of the Amazon region: humification, recalcitrance, and dating. Sci Total Environ. 2018;613-614:160-7. https://doi.org/10.1016/j.scitotenv.2017.09.068

Teixeira PC, Donagemma GK, Fontana A, Teixeira WG. Manual de métodos de análise de solo. 3. ed. rev e ampl. Brasília, DF: Embrapa; 2017.

Valerio MW, McDaniel PA, Gessler PE. Distribution and properties of podzolized soils in the northern Rocky Mountains. Soil Sci Soc Am J. 2016;80:1308-16. https://doi.org/10.2136/sssaj2016.04.0109

Vepraskas MJ. Redoximorphic features for identifying aquic conditions. North Carolina: North Carolina State University; 2015.

Zani H, Assine ML, Mcglue MM. Remote sensing analysis of depositional landforms in alluvial settings: method development and application to the Taquari Megafan, Pantanal (Brazil). Geomorphology. 2012;161-162:82-92. https://doi.org/10.1016/j.geomorph.2012.04.003 